\title{
Ancestral Caddo Ceramic Vessels from East Texas Sites Held by the Gila Pueblo Museum from 1933 to 2017
}

Timothy K. Perttula

Heritage Research Center, Stephen F. Austin State University

Kevin Stingley

Texas Archeological Stewardship Network, Texas Historical Commission

Follow this and additional works at: https://scholarworks.sfasu.edu/ita

Part of the American Material Culture Commons, Archaeological Anthropology Commons, Environmental Studies Commons, Other American Studies Commons, Other Arts and Humanities Commons, Other History of Art, Architecture, and Archaeology Commons, and the United States History Commons

Tell us how this article helped you.

This Article is brought to you for free and open access by the Center for Regional Heritage Research at SFA ScholarWorks. It has been accepted for inclusion in Index of Texas Archaeology: Open Access Gray Literature from the Lone Star State by an authorized editor of SFA ScholarWorks. For more information, please contact cdsscholarworks@sfasu.edu. 


\section{Ancestral Caddo Ceramic Vessels from East Texas Sites Held by the Gila Pueblo Museum from 1933 to 2017}

\section{Creative Commons License}

\section{(c) (1) \&}

This work is licensed under a Creative Commons Attribution-NonCommercial 4.0 International License 


\title{
Ancestral Caddo Ceramic Vessels from East Texas Sites Held by the Gila Pueblo Museum from 1933 to 2017
}

\author{
Timothy K. Perttula and Kevin Stingley
}

\section{Introduction}

In the summer of 2017, 21 ancestral Caddo ceramic vessels held since 1933 by the Gila Pueblo Museum and then by the Arizona State Museum were returned to the Texas Archeological Research Laboratory at The University of Texas at Austin (TARL). These vessels had not been properly or fully studied and documented when the University of Texas exchanged these vessels, so our purpose in documenting these vessels now is primarily concerned with determining the stylistic (i.e., decorative methods, motifs, and decorative elements) and technological (i.e., vessel form, temper, and vessel size) character of the vessels that are in the collection, and assessing their cultural relationships and stylistic associations, along with their likely age. In 1933, little was known about the cultural and temporal associations of ancestral Caddo ceramic vessels from East Texas, but that has changed considerably since that time (e.g., Perttula 2013).

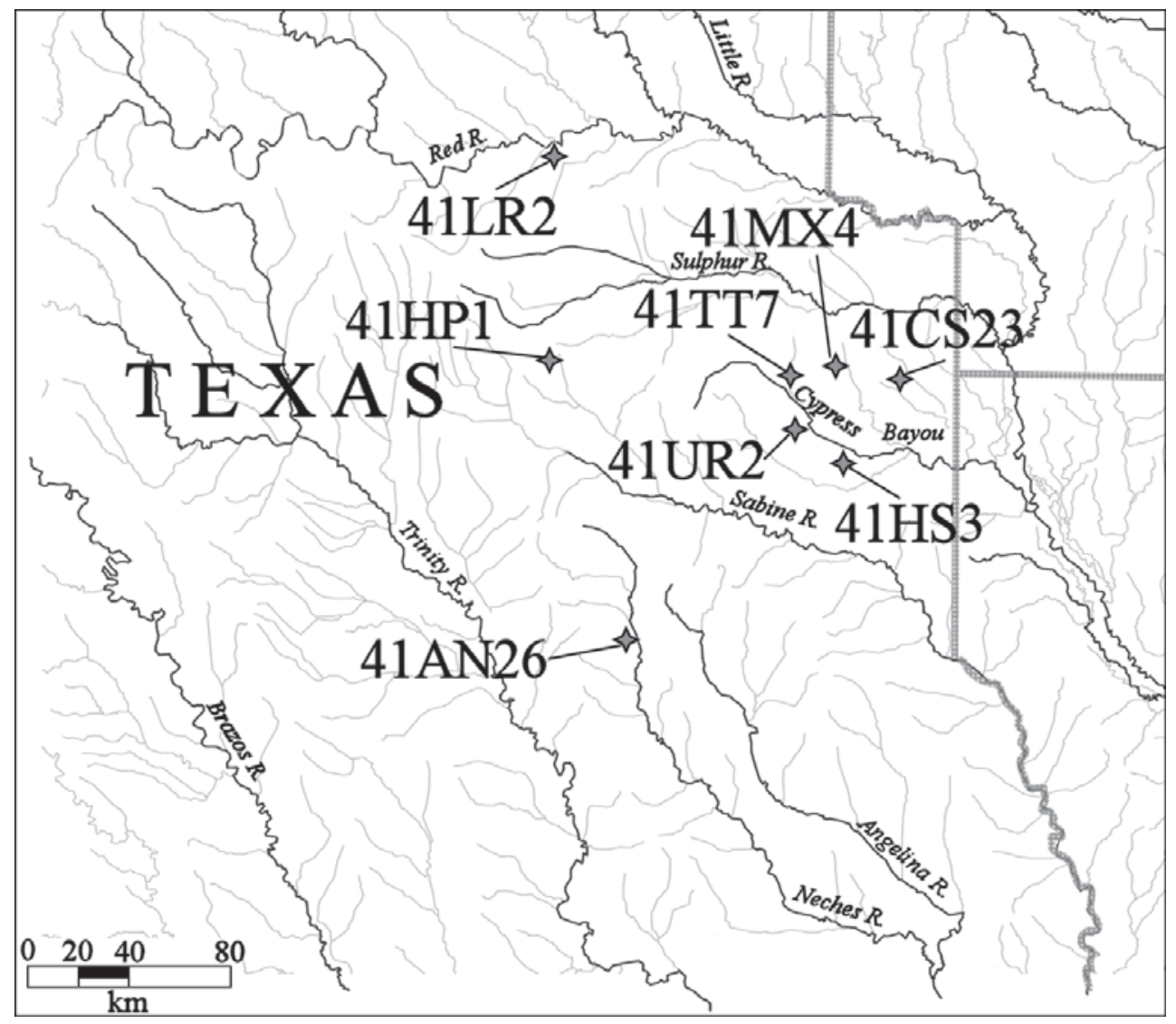

Figure 1. Locations of the sites in East Texas with exchanged vessels. 


\section{Ceramic Vessel Exchange}

Harold Gladwin of the Gila Pueblo Museum (GPM) in Globe, Arizona, first proposed to The University of Texas (UT) an exchange of ceramic materials in November 1931 with Dr. J. E. Pearce of UT. Pearce was not prepared to exchange any ceramic vessels or sherd collections at that time because the ceramic materials in his possession had not been studied since they had been recovered from excavations at East Texas Caddo sites.

However, by November 1933, Pearce felt an exchange of Southwestern vessels with ancestral Caddo vessels between the GPM and UT was worth doing, and 20 Caddo vessels from eight East Texas sites were selected by E. B. Sayles of the GPM. After Pearce obtained permission from UT President H. Y. Benedict and the Board of Regents on November 7 and 24, respectively, the vessels were shipped to the GPM. The eight ancestral Caddo sites that had vessels selected for the exchange included the Richard Patton Farm (41AN26, 2 vessels); Goode Hunt Farm (41CS23, 2 vessels); Mrs. H. L. Culpepper Farm (41HP1, 1 vessel); H. R. Taylor (41HS3, 7 vessels); T. M. Sanders Farm (41LR2, 2 vessels); Hooper Glover Farm (41MX4, 1 vessel); Russell Bros. Farm (41TT7, 1 vessel); and the J. M. Riley Farm (41UR2, 4 vessels). The vessels remained in Arizona museums until the summer of 2017.

\section{Richard Patton Site (41AN26)}

The Richard Patton site has ancestral Caddo habitation deposits of historic Allen phase age (ca. A.D. 1680-1720) as well as a small cemetery in the upper Neches River basin. The landowner, Mr. Patton, located and excavated 12 burials there, in two north-south rows, and recovered 29 ceramic vessels (Cole 1975:129). These vessels were purchased in 1933 by UT (Marceaux 2011:418). Two blue glass beads were found in one burial re-investigated by UT in 1933 (Cole 1975:Table 8).

Vessels in the cemetery were primarily globular bowls, carinated bowls, and bowls (Perttula et al. 2015:Table 1). Ceramic types included Patton Engraved, var. Allen, var. Fair, var. Freeman, and var. Patton, one Patton Incised vessel, and three Poynor Engraved vessels (Perttula et al. 2015:Table 3).

SITE NAME OR SITE NUMBER: Richard Patton (41AN26)

VESSEL NO.: 2, GP 41057, TARL 2017.0131

VESSEL FORM: Carinated bowl

NON-PLASTICS AND PASTE: grog and hematite temper

RIM AND LIP FORM: Inverted rim and rounded lip

CORE COLOR: $\mathrm{G}$ (fired in a reducing environment and cooled in the open air)

INTERIOR SURFACE COLOR: very dark grayish-brown; fire clouds on the rim and body

EXTERIOR SURFACE COLOR: light brown; fire clouds on the rim, body, and base

WALL THICKNESS (IN MM): rim, 6.5

INTERIOR SURFACE TREATMENT: smoothed

EXTERIOR SURFACE TREATMENT: none

HEIGHT (IN CM): 14.8 
ORIFICE DIAMETER (IN CM): 21.5

DIAMETER AT BOTTOM OF RIM OR NECK (IN CM): 21.9

BASE DIAMETER (IN CM) AND SHAPE OF BASE: $9.5 \mathrm{~cm}$, circular and flat

ESTIMATED VOLUME (IN

LITERS): 2.8

DECORATION (INCLUDING MOTIF AND ELEMENTS WHEN APPARENT): The upper and lower portions of the carinated rim panel have a single horizontal engraved line with excised tick marks. Between these horizontal lines are three sets of five opposed curvilinear engraved lines with outward-pointing excised tick marks. The centermost curvilinear engraved line is not divided into two opposed sections. The vessel body has horizontal brushing marks (Figure 2).

PIGMENT USE AND LOCATION ON VESSEL: none

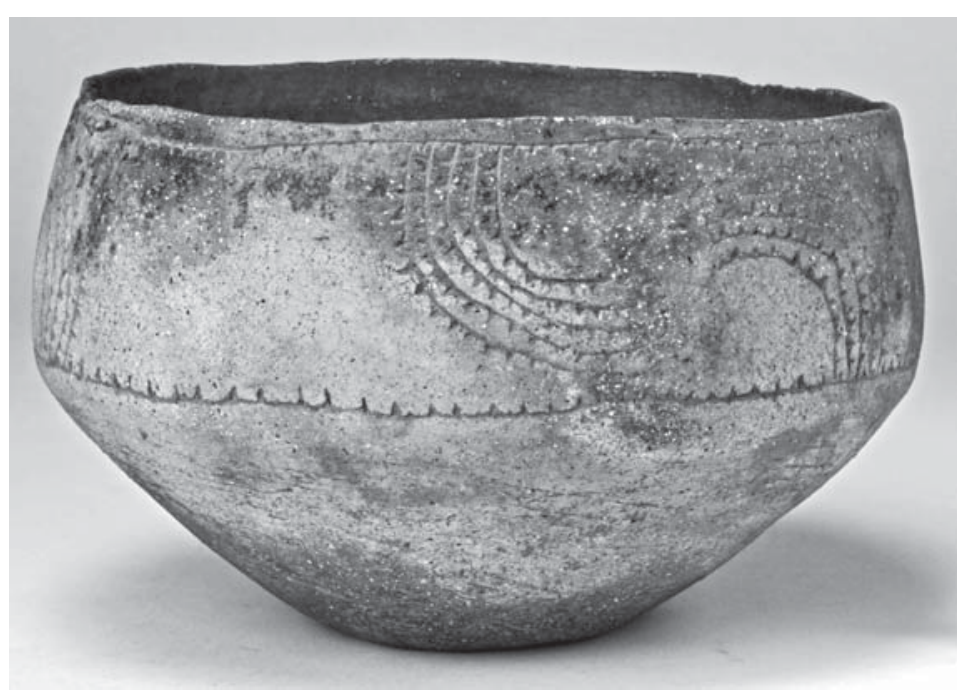

Figure 2. Patton Engraved, var. Patton carinated bowl from the Richard Patton site (41AN26).

TYPE AND VARIETY (IF KNOWN): Patton Engraved, var. Patton (Perttula 2011)

SITE NAME OR SITE NUMBER: Richard Patton (41AN26)

VESSEL NO.: 23, GP 41056, TARL 2017.0131

VESSEL FORM: Jar

NON-PLASTICS AND PASTE: hematite and a sandy paste

RIM AND LIP FORM: Direct rim and rounded lip

CORE COLOR: $\mathrm{G}$ (fired in a reducing environment and cooled in the open air)

INTERIOR SURFACE COLOR: light grayish-brown; fire clouds on the rim, body, and base

EXTERIOR SURFACE COLOR: light reddish-brown; fire clouds on the rim, body, and base

WALL THICKNESS (IN MM): rim, 4.9

INTERIOR SURFACE TREATMENT: none

EXTERIOR SURFACE TREATMENT: none

HEIGHT (IN CM): 10.4 
ORIFICE DIAMETER (IN CM): 9.4

\section{DIAMETER AT BOTTOM OF RIM OR NECK (IN CM): 8.9}

\section{BASE DIAMETER (IN CM) AND SHAPE \\ OF BASE: $6.3 \mathrm{~cm}$, circular and flat}

\section{ESTIMATED VOLUME (IN LITERS): 0.6}

DECORATION (INCLUDING MOTIF AND ELEMENTS WHEN APPARENT): The rim panel has nine sets of rectangular sections defined by single vertical engraved lines and upper and lower horizontal engraved lines. The upper and lower horizontal engraved lines have sets of upward- or downwardpointing excised tick marks or triangles. The vessel body has three sets of curvilinear and concentric circular engraved lines around a small central circle element; these lines all have outward-pointing excised tick marks. Dividing each of the sets of curvilinear and concentric engraved lines are large open pendant triangles with a short vertical engraved line extending from the apex of the pendant triangle (Figure 3).

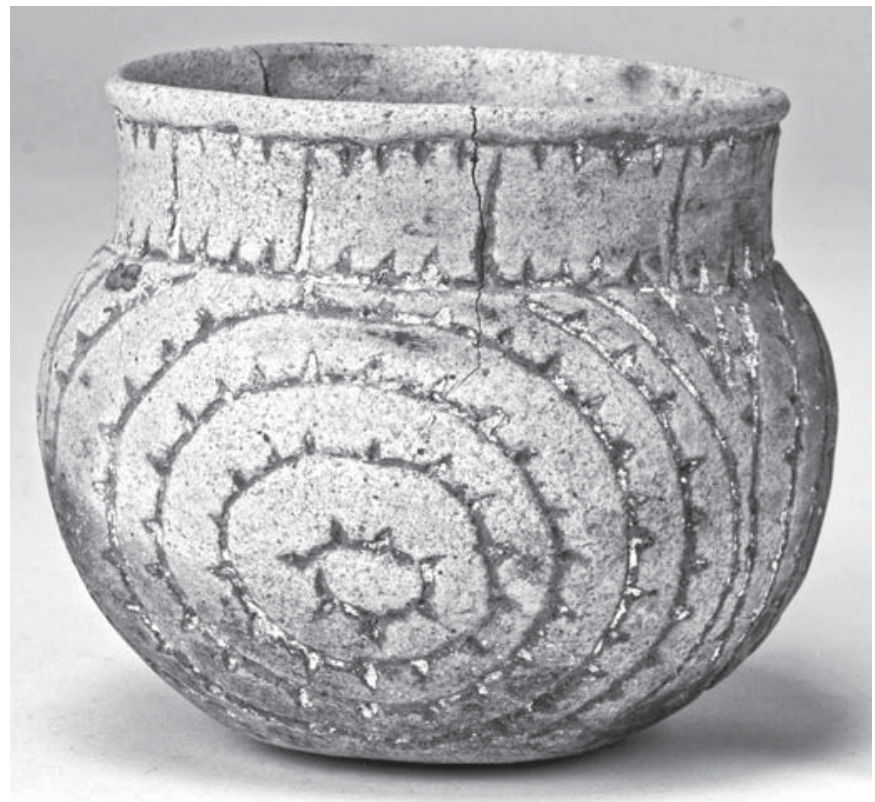

Figure 3. Patton Engraved, var. Freeman jar from the Richard Patton site (41AN26).

PIGMENT USE AND LOCATION ON VESSEL: white pigment in engraved lines

TYPE AND VARIETY (IF KNOWN): Patton Engraved, var. Freeman (see Perttula 2011)

\section{Goode Hunt Site (41CS23)}

The Goode Hunt site is an early historic Nasoni Caddo cemetery in the Black Bayou basin in the East Texas Pineywoods. UT archaeologists investigated the site in 1932 (Perttula 2015). The UT excavations identified 17 ancestral Caddo burials in two or three roughly northeast-southwest-oriented rows in a large area on the knoll opened by wide-spread and eventually contiguous shovel trenching (Perttula 2015:Figure 3).

The principal funerary offering in the ancestral Caddo burials from the Goode Hunt site is ceramic vessels of varying form and decorative motifs/elements. According to Jackson (1932), the 17 graves had 76 ceramic vessels as funerary offerings, with a mean of 4.5 vessels per grave and a range of one to nine vessels; 69 vessels were documented by Perttula (2015). One burial had a ceramic elbow pipe, and seven of the burials had either chipped or ground stone tools. Five burials had mussel shell hoes, and another (Burial I-10) had a mussel shell valve placed inside one of the ceramic vessels. Burial I-15 had a deer mandible in the grave. Five of the Goode Hunt burials had pigment offerings (gray, green, and red). Burial I-7 had a thin piece of metal placed in the grave above the head of the deceased.

The ceramic vessels from the Goode Hunt site are primarily carinated bowls, jars, and bottles, and they have been tempered with grog, bone, and shell. The utility wares placed as funerary offerings in the graves include Foster Trailed-Incised, Karnack Brushed-Incised, Maydelle Incised, Mockingbird Punctated, Moore Noded, and Pease Brushed-Incised, there are plain jars, and the fine wares are dominated by Simms Engraved and Hodges Engraved types, as well as Taylor Engraved, Keno Trailed, and Hatchel Engraved (Perttula 2015:Tables 7-8). 
SITE NAME OR SITE NUMBER: Goode Hunt (41CS23)

VESSEL NO.: 61, Burial I-7, GP 41058, TARL 2017.0131

VESSEL FORM: Carinated bowl

NON-PLASTICS AND PASTE: grog and a sandy paste

RIM AND LIP FORM: Inverted rim and rounded lip

CORE COLOR: B (fired and cooled in a reducing environment)

INTERIOR SURFACE COLOR: black EXTERIOR SURFACE COLOR: black

WALL THICKNESS (IN MM): rim, 3.2

INTERIOR SURFACE TREATMENT: burnished

EXTERIOR SURFACE TREATMENT: burnished

HEIGHT (IN CM): 6.4

ORIFICE DIAMETER (IN CM): 12.7

DIAMETER AT BOTTOM OF RIM OR NECK (IN CM): 14.3

BASE DIAMETER (IN CM) AND SHAPE OF BASE: $5.3 \mathrm{~cm}$, circular and convex

ESTIMATED VOLUME (IN LITERS): 0.5

DECORATION (INCLUDING MOTIF AND ELEMENTS WHEN APPARENT): The upper half of the rim panel is plain. The lower half of the rim panel has an engraved motif repeated three times, and
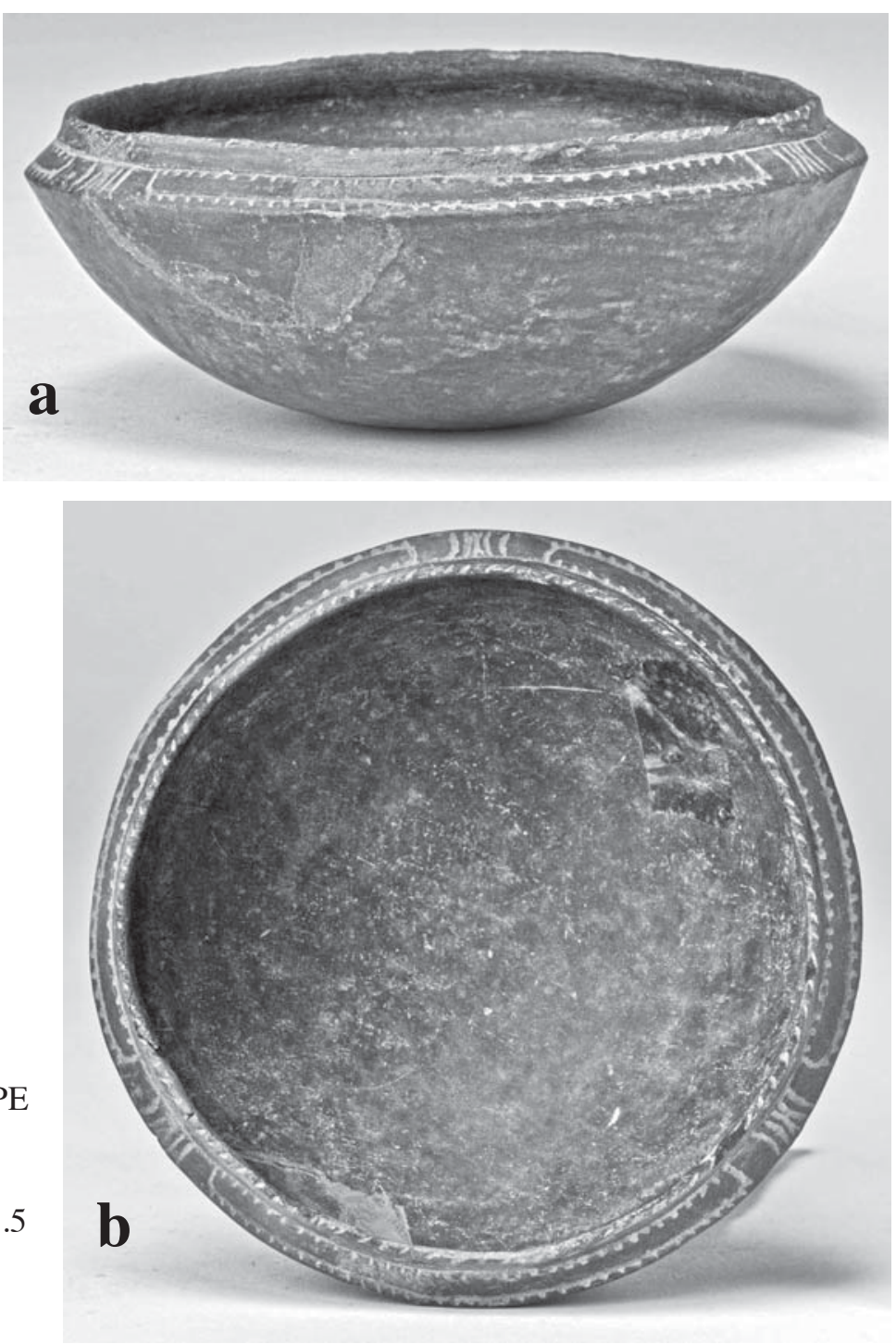

Figure 4. Simms Engraved carinated bowl from the Goode Hunt site (41CS23): a, side view; b, view of notched lip. divided by vertical bracket elements. The motif consists of rectangular zones with rounded ends, and the upper and lower parts of the rectangular zones have small excised tick marks (Figure 4a). The vessel is also lip notched (from right to left) (Figure 4b) and has a black slip on both interior and exterior surfaces.

PIGMENT USE AND LOCATION ON VESSEL: none

TYPE AND VARIETY (IF KNOWN): Simms Engraved (see Suhm and Jelks 1962:Plate 71) 
SITE NAME OR SITE NUMBER: Goode Hunt (41CS23)

VESSEL NO.: 103, Burial I-15, GP 41059, TARL 2017.0131

VESSEL FORM: Carinated bowl

NON-PLASTICS AND PASTE: grog

RIM AND LIP FORM: Direct rim and rounded lip

CORE COLOR: B (fired and cooled in a reducing environment)

INTERIOR SURFACE COLOR: very dark brown on the rim, and very dark grayish-brown on the body and base

EXTERIOR SURFACE COLOR: very dark brown

WALL THICKNESS (IN MM): rim, $7.6 \mathrm{~mm}$

INTERIOR SURFACE TREATMENT: smoothed on the rim

EXTERIOR SURFACE TREATMENT: burnished

HEIGHT (IN CM): 8.2

ORIFICE DIAMETER (IN CM): 14.8

DIAMETER AT BOTTOM OF RIM OR NECK (IN CM): 14.7

BASE DIAMETER (IN CM) AND SHAPE OF BASE: $7.0 \mathrm{~cm}$, circular and flat

ESTIMATED VOLUME (IN

LITERS): 0.7

DECORATION (INCLUDING

MOTIF AND ELEMENTS WHEN

APPARENT): The rim panel is divided into four sections by vertical bracket elements comprised of two sets of vertical curvilinear engraved lines and a central excised punctation. Within each section is a horizontal scroll line with rounded ends and single upper and lower excised tick marks (Figure 5).

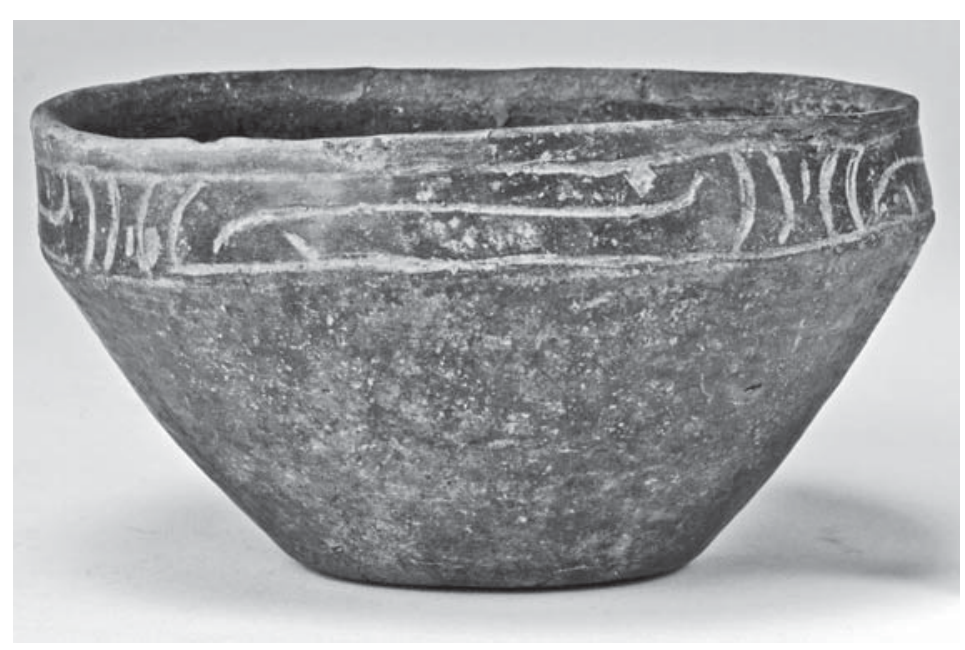

Figure 5. Simms Engraved carinated bowl from Burial I-15 at the Goode Hunt site.

PIGMENT USE AND LOCATION

ON VESSEL: red pigment in engraved lines

TYPE AND VARIETY (IF KNOWN): Simms Engraved 


\section{Culpepper Site (41HP1)}

The Culpepper site (41HP1) is a late (post-A.D. 1600) Titus phase site in the upper Sulphur River basin in East Texas. It is on a sandy knoll alongside Stouts Creek, a small northward-flowing stream in the White Oak Creek basin of the larger Sulphur River drainage. Excavations at the Culpepper site by UT archaeologists in 1931 uncovered eight ancestral Caddo burial features with 39 associated ceramic vessel funerary offerings and Talco arrow points (Scurlock 1962; Perttula 2016); collectors had previously excavated 14 burials there and recovered 25 ceramic vessels.

The vessels from the burial features at the Culpepper site are dominated by fine wares: engraved bottles, bowls, carinated bowls, and jars, a number of which are also red-slipped on interior and exterior surfaces. Defined ceramic types in the vessel assemblage from the Culpepper site include Harleton Appliqued and La Rue Neck Banded jars, all grog-tempered, and several fine ware types. The most common fine ware is grog-tempered Ripley Engraved (38 percent of the fine ware vessels), including vessels of var. Carpenter, var. Galt, var. Gandy, and var. Pilgrims; var. Gandy vessels with engraved scroll motifs are particularly well represented. Other grog-tempered fine ware types are Keno Trailed, Simms Engraved, Simms Engraved, var. Darco, Taylor Engraved, Wilder Engraved, var. Ebenezer, and Womack Engraved, var. Culpepper. The Culpepper site and other Titus phase sites along Stouts Creek are part of a very distinctive western Titus phase community that lived in the Post Oak Savannah in the Stouts Creek valley in the late $16^{\text {th }}$ century and much of the $17^{\text {th }}$ century A.D. (Perttula 2016). The stylistic character of the ceramic vessels from the Culpepper site suggest the cemetery there was used by Caddo peoples in the $17^{\text {th }}$ century, perhaps as late as ca. A.D. 1680, prior to any sustained contact between Caddo groups and European explorers and traders.

SITE NAME OR SITE NUMBER: Culpepper site (41HP1)

VESSEL NO.: 33, GP 41062, TARL 2017.0131

VESSEL FORM: Carinated bowl

NON-PLASTICS AND PASTE: grog

RIM AND LIP FORM: Inverted rim and rounded lip

CORE COLOR: F (fired in a reducing environment and cooled in the open air)

INTERIOR SURFACE COLOR: red

EXTERIOR SURFACE COLOR: red

WALL THICKNESS (IN MM): rim, $4.2 \mathrm{~mm}$

INTERIOR SURFACE TREATMENT: smoothed

EXTERIOR SURFACE TREATMENT: burnished

HEIGHT (IN CM): 9.0

ORIFICE DIAMETER (IN CM): 14.0

DIAMETER AT BOTTOM OF RIM OR NECK (IN CM): 15.0 
BASE DIAMETER (IN CM) AND SHAPE OF BASE: $5.0 \mathrm{~cm}$, circular and flat

\section{ESTIMATED VOLUME (IN LITERS): 0.8}

\section{DECORATION (INCLUDING} MOTIF AND ELEMENTS WHEN APPARENT): The rim panel has four sets of slanting engraved scroll lines on either side of a hooked arm element. The upper and lower scroll fill zones have excised columns and negative zones (Figure 6).

\section{PIGMENT USE AND LOCATION ON VESSEL: none}

TYPE AND VARIETY (IF KNOWN): Taylor Engraved (Suhm and Jelks 1962:Plate 75)

\section{H. R. Taylor Site (41HS3)}

The H. R. Taylor site (41HS3) is a large ancestral Caddo community cemetery in the Pineywoods of East Texas that was used during the latter years (ca. A.D. 1550-1680 or ca. A.D. 1600-1680) of the Late Caddo period Titus phase. The cemetery was excavated in the summer of 1931 by UT (Pearce and Jackson 1931), after the cemetery had been discovered by local persons in 1929 when erosion exposed vessels in a plowed field. Local diggers, including J. H. Chadd, had excavated perhaps five to seven burials and recovered about 20 ceramic vessels sometime prior to the UT work (Pearce and Jackson 1931; Thurmond 1990:161).

The cemetery at the H. R. Taylor site is located on an upland landform just west of Copeland Creek, a northward-flowing tributary to Big Cypress Creek. The UT excavations, which began as north-south trenches just west of Copeland Creek, exposed 64 individual extended burials in a ca. 36 x 24 m area (Perttula 2017:Figure 2). A total of 527 ancestral Caddo ceramic vessels had been placed as funerary offerings in the burial features, along with ceramic pipes, ceramic clay ear spools, arrow points, celts, paint stones, smoothing stones, and two large Galt bifaces (Perttula 2017:Table 1).

The ceramic vessels are primarily carinated bowls, jars, and bottles, and they are tempered almost exclusively with grog. Among the ceramic types that are considered to have been locally manufactured for use in the community cemetery at the H. R. Taylor site, the most common types comprise the set of Ripley Engraved (all varieties, 39.7 percent, but especially var. McKinney), Taylor Engraved (13.3 percent), Karnack Brushed-Incised (10.3 percent), Wilder Engraved (all varieties, 5.6 percent), and Harleton Appliqued (5.4 percent) (Perttula 2017:Table 18).

SITE NAME OR SITE NUMBER: H. R. Taylor (41HS3)

VESSEL NO.: 230, GP 41043, TARL 2017.0131

VESSEL FORM: Jar 
NON-PLASTICS AND PASTE: grog

RIM AND LIP FORM: Everted rim and rounded lip

CORE COLOR: $\mathrm{F}$ (fired in a reducing environment and cooled in the open air)

INTERIOR SURFACE COLOR: brown; fire clouds on the rim and body

EXTERIOR SURFACE COLOR: brown; fire clouds on the body and base

WALL THICKNESS (IN MM): rim, $7.3 \mathrm{~mm}$

INTERIOR SURFACE TREATMENT: smoothed

EXTERIOR SURFACE TREATMENT: none

HEIGHT (IN CM): 24.3

ORIFICE DIAMETER (IN CM): 19.8

DIAMETER AT BOTTOM OF RIM OR NECK (IN CM): 19.4

BASE DIAMETER (IN CM) AND SHAPE

OF BASE: $8.0 \mathrm{~cm}$, circular and flat

ESTIMATED VOLUME (IN LITERS): 4.3

DECORATION (INCLUDING MOTIF AND ELEMENTS WHEN APPARENT): The vessel rim has a single horizontal incised line at the rim-body juncture and vertical incised lines on the rim itself. The vessel body has vertical brushed-incised marks and lines that extend from the rim-body juncture to the base (Figure 7).

PIGMENT USE AND LOCATION ON VESSEL: none

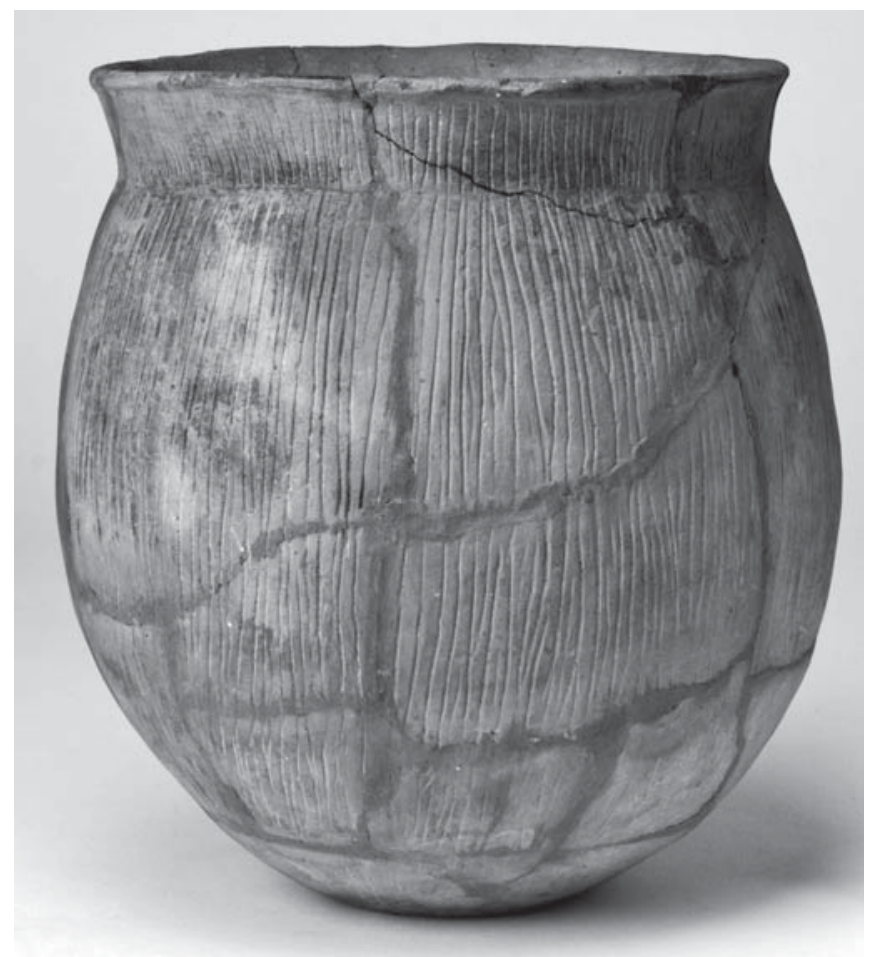

Figure 7. Karnack Brushed-Incised jar from the H. R. Taylor site (41HS3).

TYPE AND VARIETY (IF KNOWN): Karnack Brushed-Incised (see Suhm and Jelks 1962:Plate 43)

SITE NAME OR SITE NUMBER: H. R. Taylor (41HS3)

VESSEL NO.: 595, GP 41045, TARL 2017.0131

VESSEL FORM: Compound bowl

NON-PLASTICS AND PASTE: bone and hematite

RIM AND LIP FORM: Everted rim and rounded lip 
CORE COLOR: $\mathrm{F}$ (fired in a reducing environment and cooled in the open air)

INTERIOR SURFACE COLOR: brown; fire clouds on the rim and body

EXTERIOR SURFACE COLOR: brown; fire clouds on the rim, body, and base

WALL THICKNESS (IN MM): rim, upper panel, 7.7

INTERIOR SURFACE TREATMENT: smoothed

EXTERIOR SURFACE TREATMENT: smoothed

HEIGHT (IN CM): 26.0

ORIFICE DIAMETER (IN CM): 33.3

DIAMETER AT BOTTOM OF RIM OR NECK (IN CM): 31.7 (at upper panel), 34.1 (at lower panel)

BASE DIAMETER (IN CM) AND SHAPE

OF BASE: $10.8 \mathrm{~cm}$, circular and flat

ESTIMATED VOLUME (IN LITERS): 7.0

DECORATION (INCLUDING MOTIF AND ELEMENTS WHEN APPARENT):

The upper rim panel has two widelyspaced horizontal engraved lines. The lower rim panel has four sets of horizontal interlocking scrolls, with the central scroll line connecting to the upper and lower parts of the panel by vertical excised brackets; each bracket has a negative pendant triangle element. The interlocking scrolls are divided by large open vertical bracket elements. The vessel body has diagonal brushing marks (Figure 8a-b).

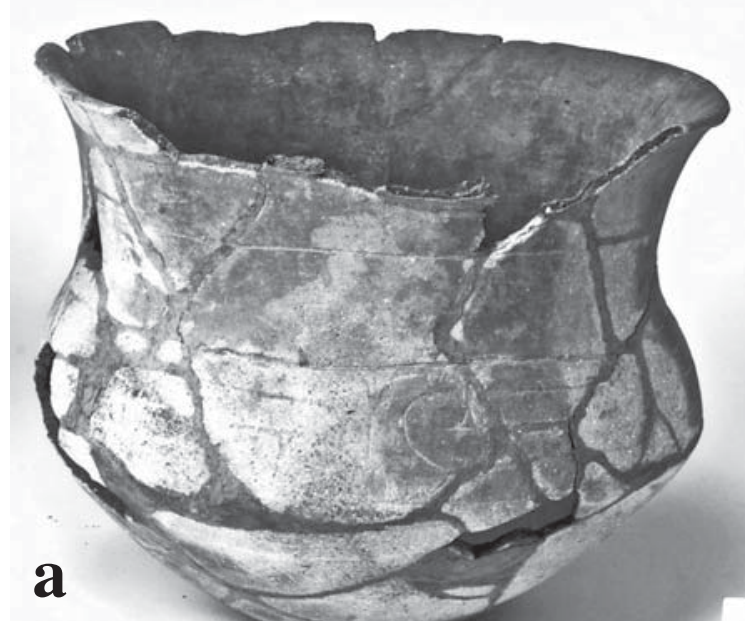

PIGMENT USE AND LOCATION ON

VESSEL: none

TYPE AND VARIETY (IF KNOWN): Ripley Engraved, var. Pilgrims (see Fields et al. 2014; Perttula et al. 2012)

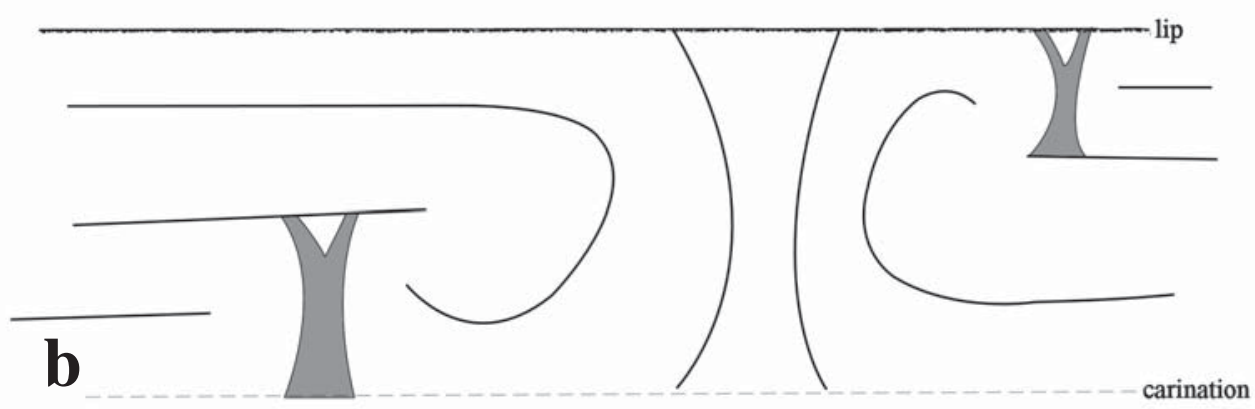

Figure 8. Ripley Engraved, var. Pilgrims compound bowl from the H. R. Taylor site: a, side view; b, selected decorative elements on lower rim panel. 
SITE NAME OR SITE NUMBER: H. R. Taylor (41HS3)

VESSEL NO.: 617, GP 41044, TARL 2017.0131

VESSEL FORM: Jar

NON-PLASTICS AND PASTE: bone

RIM AND LIP FORM: Everted rim and rounded lip

CORE COLOR: B (fired and cooled in a reducing environment)

INTERIOR SURFACE COLOR: very dark grayish-brown; fire clouds on the rim and body

EXTERIOR SURFACE COLOR: grayish-brown; fire clouds on the rim and body; organic residue on the body

WALL THICKNESS (IN MM): rim, 8.4

INTERIOR SURFACE TREATMENT: smoothed

EXTERIOR SURFACE TREATMENT: none

HEIGHT (IN CM): 16.4

ORIFICE DIAMETER (IN CM): 12.5

DIAMETER AT BOTTOM OF RIM OR NECK (IN CM): 12.1

BASE DIAMETER (IN CM) AND SHAPE OF BASE: $6.4 \mathrm{~cm}$, circular and flat

ESTIMATED VOLUME (IN LITERS): 1.2

DECORATION (INCLUDING MOTIF AND ELEMENTS WHEN APPARENT): The rim of the vessel is decorated with diagonal incised lines. The vessel body has vertical brushing marks that extend to within $2.5 \mathrm{~cm}$ of the base (Figure 9).

PIGMENT USE AND LOCATION ON VESSEL: none

TYPE AND VARIETY (IF KNOWN): Karnack Brushed-Incised

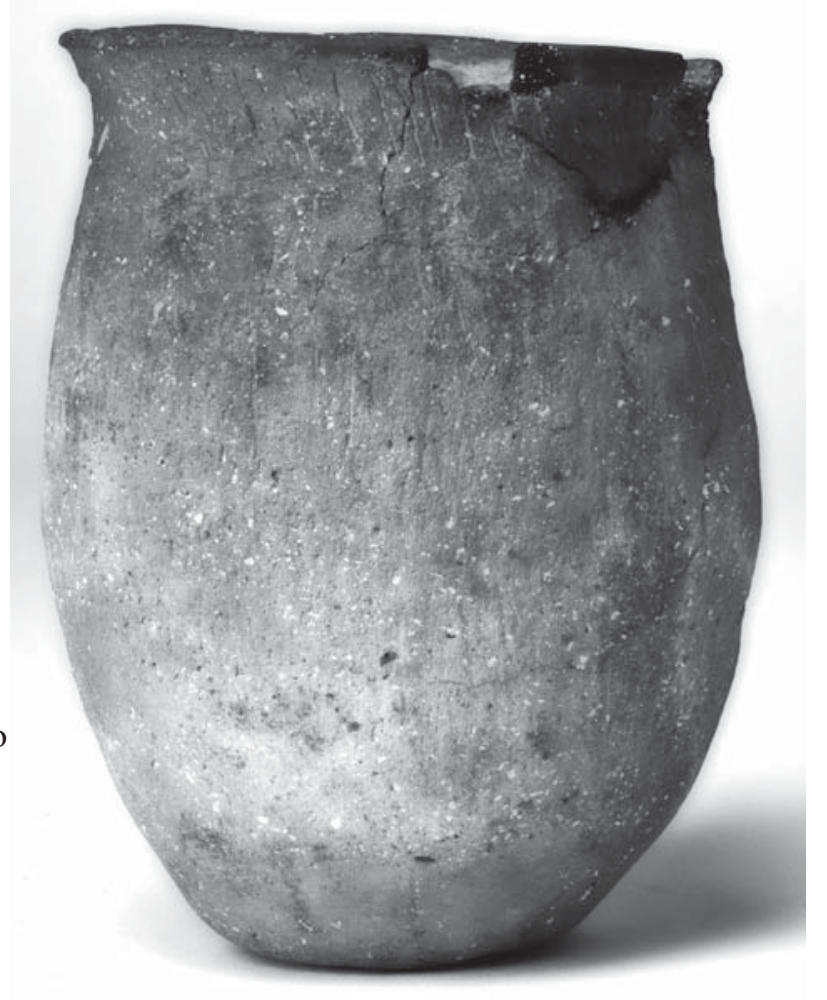

Figure 9. Karnack Brushed-Incised jar from the H. R. Taylor site (41HS3). 
SITE NAME OR SITE NUMBER: H. R. Taylor (41HS3)

VESSEL NO.: 695, GP 41047, TARL 2017.0131

VESSEL FORM: Jar with four rim peaks and four handles at the rim peaks; the handles are $20 \times 15 \mathrm{~mm}$ in height and width

NON-PLASTICS AND PASTE: grog and bone

RIM AND LIP FORM: Everted rim and rounded lip

CORE COLOR: $\mathrm{F}$ (fired in a reducing environment and cooled in the open air)

INTERIOR SURFACE COLOR: reddish-brown; fire clouds on the rim and body

EXTERIOR SURFACE COLOR: brown; fire clouds on the rim and body

WALL THICKNESS (IN MM): rim, 6.2

INTERIOR SURFACE TREATMENT: smoothed

EXTERIOR SURFACE TREATMENT: none

HEIGHT (IN CM): 15.7

ORIFICE DIAMETER (IN CM): 14.7

DIAMETER AT BOTTOM OF RIM OR

NECK (IN CM): 15.0

BASE DIAMETER (IN CM) AND SHAPE

OF BASE: $6.4 \mathrm{~cm}$, circular and flat

ESTIMATED VOLUME (IN LITERS): 1.4

DECORATION (INCLUDING MOTIF AND ELEMENTS WHEN APPARENT): The rim of the vessel has vertical incised lines. The vessel body has horizontal appliqued fillets at the top and bottom, as well as four sets of appliqued fillet scrolls and circles (with a central inner appliqued node). There are sets of curvilinear appliqued fillets both above and below the scroll and circle elements, as well as four upper appliqued pendant triangles that divide the scrolls. The areas between the curvilinear fillets and the scroll and circle elements have curvilinear or horizontal brushed marks and

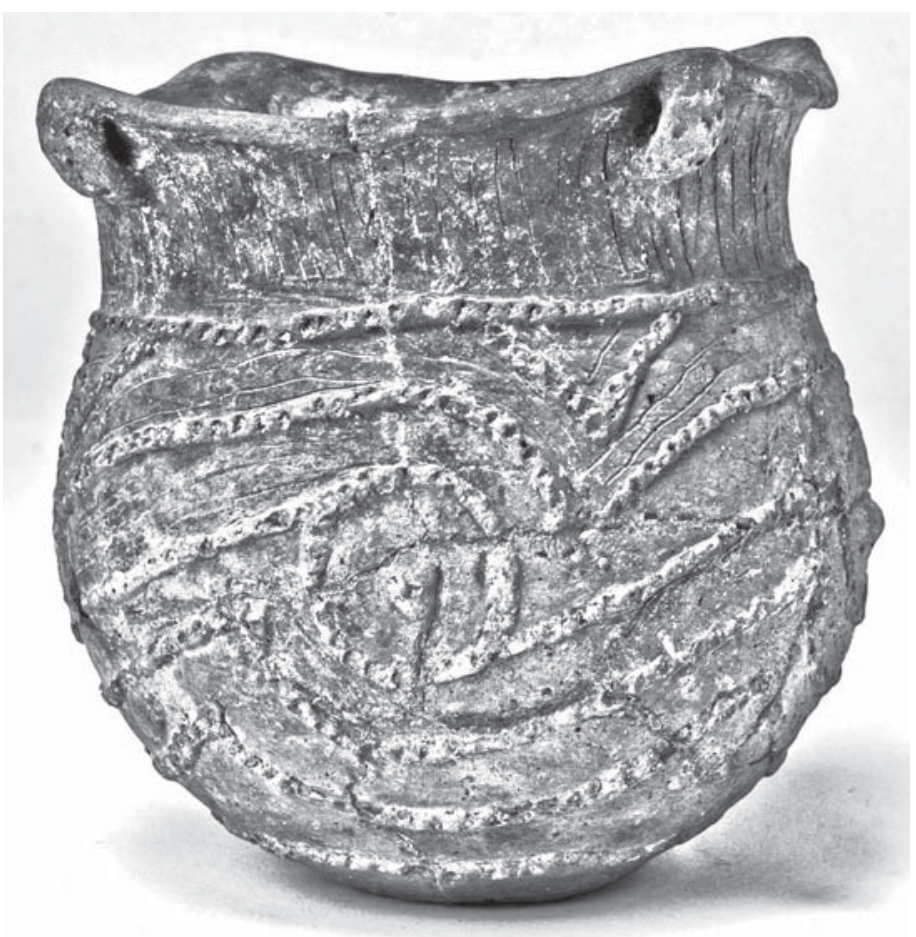

Figure 10. Harleton Appliqued jar from the H. R. Taylor site (41HS3). incised lines. The four handles have rows of tool punctations (Figure 10). 
SITE NAME OR SITE NUMBER: H. R. Taylor (41HS3)

VESSEL NO.: 768, GP 41046, TARL 2017.0131

VESSEL FORM: Carinated bowl

NON-PLASTICS AND PASTE: grog

RIM AND LIP FORM: Direct rim and rounded lip

CORE COLOR: G (fired in a reducing environment and cooled in the open air)

INTERIOR SURFACE COLOR: dark grayish-brown; fire clouds on the rim

EXTERIOR SURFACE COLOR: brown; fire clouds on the rim and body

WALL THICKNESS (IN MM): rim, $6.0 \mathrm{~mm}$

INTERIOR SURFACE TREATMENT: smoothed

EXTERIOR SURFACE TREATMENT: burnished

HEIGHT (IN CM): 9.2

ORIFICE DIAMETER (IN CM): 20.2

DIAMETER AT BOTTOM OF RIM OR NECK (IN CM): 20.6

BASE DIAMETER (IN CM) AND SHAPE OF BASE: $5.8 \mathrm{~cm}$, circular and flat

ESTIMATED VOLUME (IN LITERS): 1.1

DECORATION (INCLUDING MOTIF AND ELEMENTS WHEN APPARENT): The rim panel has sets of negative slanting scrolls outlined by six upper and lower sets of curvilinear triangle elements. These curvilinear triangles are filled with diagonal and curvilinear hatched lines (Figure 11a-b).

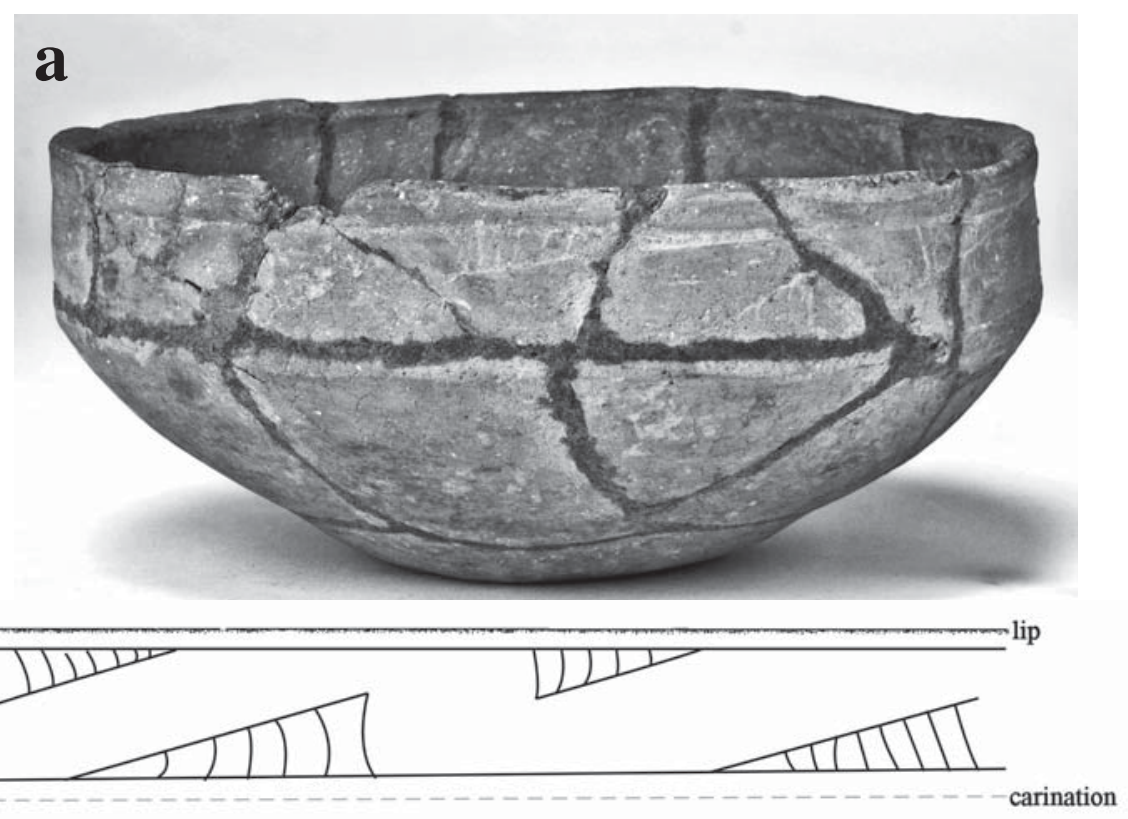

Figure 11. Engraved carinated bowl from the H. R. Taylor site (41HS3): a, side view; b, selected decorative elements.

PIGMENT USE AND LOCATION ON VESSEL: white pigment in engraved lines

TYPE AND VARIETY (IF KNOWN): Unidentified fine ware 
SITE NAME OR SITE NUMBER: H. R Taylor (41HS3)

VESSEL NO.: 804, GP 41048, TARL 2017.0131

VESSEL FORM: Carinated bowl

NON-PLASTICS AND PASTE: bone

RIM AND LIP FORM: Direct rim and rounded, exterior folded lip

CORE COLOR: F (fired in a reducing environment and cooled in the open air)

INTERIOR SURFACE COLOR: red

EXTERIOR SURFACE COLOR: red

WALL THICKNESS (IN MM): rim, $4.3 \mathrm{~mm}$

INTERIOR SURFACE TREATMENT: burnished

EXTERIOR SURFACE TREATMENT: burnished

HEIGHT (IN CM): 7.7

ORIFICE DIAMETER (IN CM): 17.8

DIAMETER AT BOTTOM OF RIM OR NECK (IN CM): 17.2

BASE DIAMETER (IN CM) AND SHAPE OF BASE: $4.4 \mathrm{~cm}$, circular and flat

ESTIMATED VOLUME (IN LITERS): 0.8

DECORATION (INCLUDING MOTIF AND ELEMENTS WHEN APPARENT): The rim panel has three sets of engraved circles and engraved diamonds with interior diamondshaped elements with negative ovals; the engraved diamonds are at the center of a horizontal-vertical scroll line that ends in upper and lower excised brackets. The horizontal lines under the lip and at the carination have excised pendant triangle elements. The interior and exterior vessel surfaces have a ochre-rich red slip (Figure 12).

\section{PIGMENT USE AND LOCATION} ON VESSEL: none

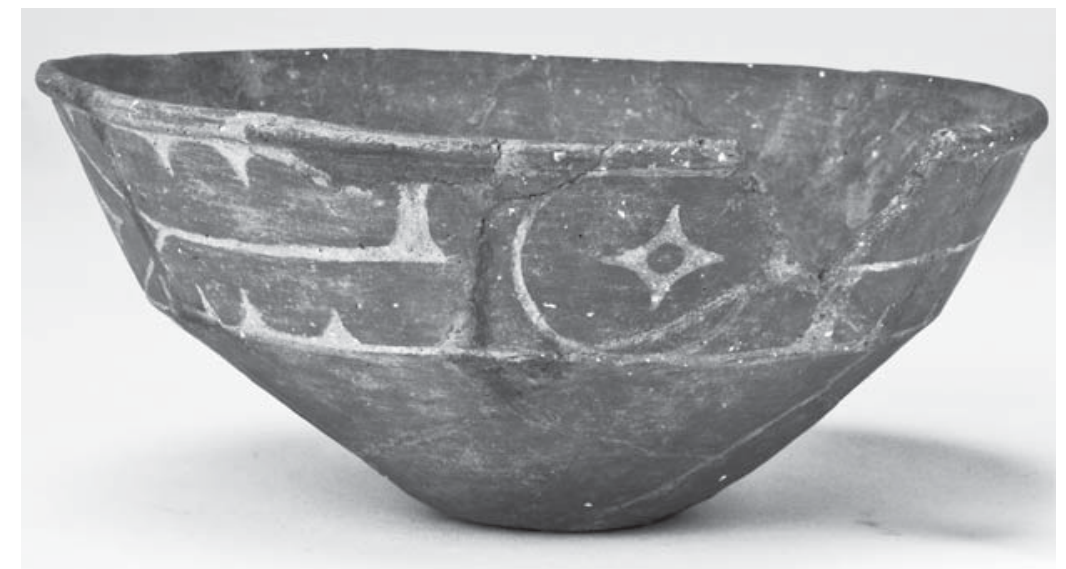

Figure 12. Ripley Engraved, var. McKinney carinated bowl from the H. R. Taylor site (41HS3).

TYPE AND VARIETY (IF KNOWN): Ripley Engraved, var. McKinney (see Fields et al. 2014; Perttula et al. 2012) 
SITE NAME OR SITE NUMBER: H. R. Taylor (41HS3)

VESSEL NO.: 864, GP 41049, TARL 2017.0131

VESSEL FORM: Bottle

NON-PLASTICS AND PASTE: grog

RIM AND LIP FORM: Everted rim and rounded lip

CORE COLOR: $\mathrm{G}$ (fired in a reducing environment and cooled in the open air)

INTERIOR SURFACE COLOR: very dark grayish-brown

EXTERIOR SURFACE COLOR: brown; fire clouds on the rim, body, and base

WALL THICKNESS (IN MM): rim, 5.1

INTERIOR SURFACE TREATMENT: none

EXTERIOR SURFACE TREATMENT: burnished

HEIGHT (IN CM): 9.6

ORIFICE DIAMETER (IN CM): 3.8

DIAMETER AT BOTTOM OF RIM OR NECK (IN CM): 3.5; maximum body diameter: $6.9 \mathrm{~cm}$

BASE DIAMETER (IN CM) AND SHAPE OF BASE: $4.6 \mathrm{~cm}$, circular and flat

ESTIMATED VOLUME (IN LITERS): 0.2

DECORATION (INCLUDING MOTIF AND ELEMENTS WHEN APPARENT): There are three horizontal engraved lines at the top of the vessel body and another horizontal engraved line above the base. Between these horizontal engraved lines are four sets of upper and lower curvilinear scrolls with hooked arm elements; the scrolls do not touch (Figure 13). There are wider excised areas on the scrolls across from the hooked arms. The scrolls begin at the apex of upper and lower engraved pendant triangles. One of the three corners of the triangles have small excised triangles, while the other two corners have small hatched or crosshatched triangles.

PIGMENT USE AND LOCATION ON VESSEL: none

TYPE AND VARIETY (IF KNOWN): Wilder Engraved, var. Ebenezer (see Perttula et al. 2017)

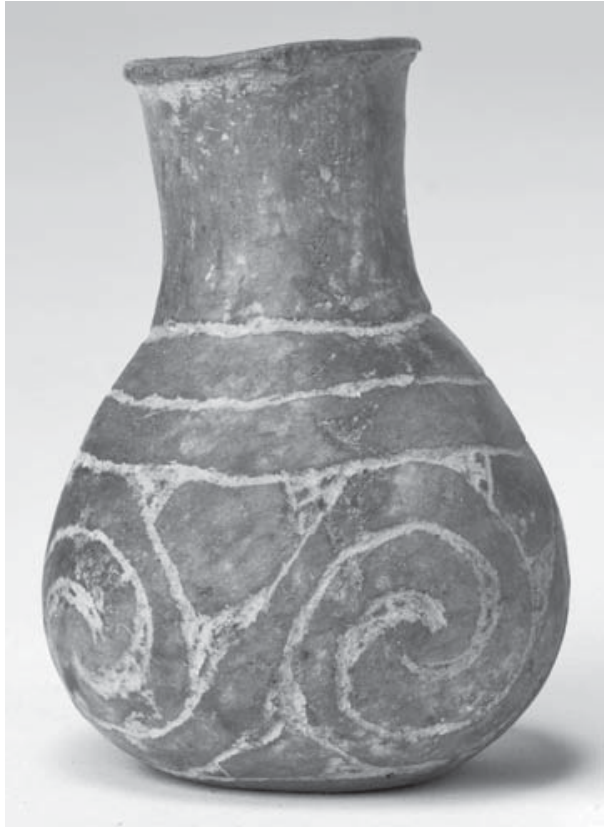

Figure 13. Wilder Engraved, var. Ebenezer bottle from the H. R. Taylor site (41HS3). 


\section{T. M. Sanders Site (41LR2)}

The T. M. Sanders site (41LR2) is an important ancestral Caddo site in East Texas, primarily because of its two earthen mounds and the well-preserved mortuary features of Caddo elite persons buried in Mound No. 1 (the East Mound); the vessels exchanged with the Gila Pueblo Museum from the site are from the East Mound. The site was excavated in July and August 1931 (Jackson et al. 2000). The Sanders site is located on a broad alluvial terrace just south of the confluence of Bois d'Arc Creek and the Red River.

Excavations in the East Mound at the T. M. Sanders site uncovered 21 burial features: 12 graves with a single individual and the other nine burials with multiple individuals (a total of 48 individuals), from three to eight people in these burial features (Perttula et al. 2016:Figure 4 and Table 1). About 76 percent of the burials had ceramic vessel funerary offerings, with a range of 1-8 vessels per burial feature. Funerary objects placed with the dead in the East Mound also included marine shell gorgets, shell beads, and arrow points, along with ceramic pipes and 60 ceramic vessels. Eleven other vessels had been purchased from the landowner in 1931, along with seven vessels from miscellaneous contexts within the site. The burial features date to the Middle Caddo period Sanders phase, likely dating from ca. A.D. 1200-1400 (Perttula et al. 2016).

The principal ceramic types at the T. M. Sanders site include Sanders Engraved ( $n=16)$, Maxey Noded Redware $(n=12)$, and a number of plain $(n=23)$ and slipped $(n=6)$ vessels; these are grog or grogbone-tempered (Perttula et al. 2016:Table 4). The plain non-slipped vessels are classified as Bois d'Arc Plain, while the slipped vessels are labeled as Sanders Slipped (Perttula et al. 2016). There are also four Monkstown Fingernail Impressed jars, two Canton Incised vessels, as well as three Sanders Incised vessels; the decorative elements on these vessels are the same as noted on a number of the Sanders Engraved vessels at the site, except that they are executed in a wet paste, not in an engraved method after the vessel was leather-hard or already fired. There are also several likely trade vessels, including a Haley Engraved vessel made by a Haley phase Caddo potter in the Great Bend area of the Red River basin, well downstream from the T. M. Sanders site. The East Incised and Hickory Engraved vessels in burials at the site may also be trade vessels whose source is elsewhere in the southern Caddo area. A unique redpainted conjoined bottle-jar in Burial 15 is likely a trade vessel of Angel Negative Painted that originated in the Angel Mounds area in the lower Ohio River valley (Baumann et al. 2013:Figure 1). The Angel Mound site was occupied from cal. A.D. 1050-1420 (Monaghan et al. 2013), generally contemporaneous with the T. M. Sanders site.

SITE NAME OR SITE NUMBER: T. M. Sanders (41LR2)

VESSEL NO.: 382, GP 41064, TARL 2017.0131

VESSEL FORM: Bottle

NON-PLASTICS AND PASTE: grog

RIM AND LIP FORM: Direct rim and rounded lip

CORE COLOR: F (fired in a reducing environment and cooled in the open air)

INTERIOR SURFACE COLOR: red

EXTERIOR SURFACE COLOR: red

WALL THICKNESS (IN MM): rim, 4.6 
INTERIOR SURFACE TREATMENT: none

EXTERIOR SURFACE TREATMENT: burnished

HEIGHT (IN CM): 14.0

ORIFICE DIAMETER (IN CM): 2.9

DIAMETER AT BOTTOM OF RIM OR NECK (IN CM):

3.7 ; maximum body diameter: $7.3 \mathrm{~cm}$

BASE DIAMETER (IN CM) AND SHAPE OF BASE: 4.0 $\mathrm{cm}$, circular and convex

ESTIMATED VOLUME (IN LITERS): 0.2

DECORATION (INCLUDING MOTIF AND ELEMENTS WHEN APPARENT): The vessel body has two horizontal rows of small tool punctations that encircle the vessel, except where they are divided by three sets of three vertical rows of appliqued nodes and tool punctations. The vessel also has a red slip on its exterior vessel surface, and at the neck on the interior surface (Figure 14).

PIGMENT USE AND LOCATION ON VESSEL: none

TYPE AND VARIETY (IF KNOWN): Maxey Noded

Redware (see Suhm and Jelks 1962:Plate 51)

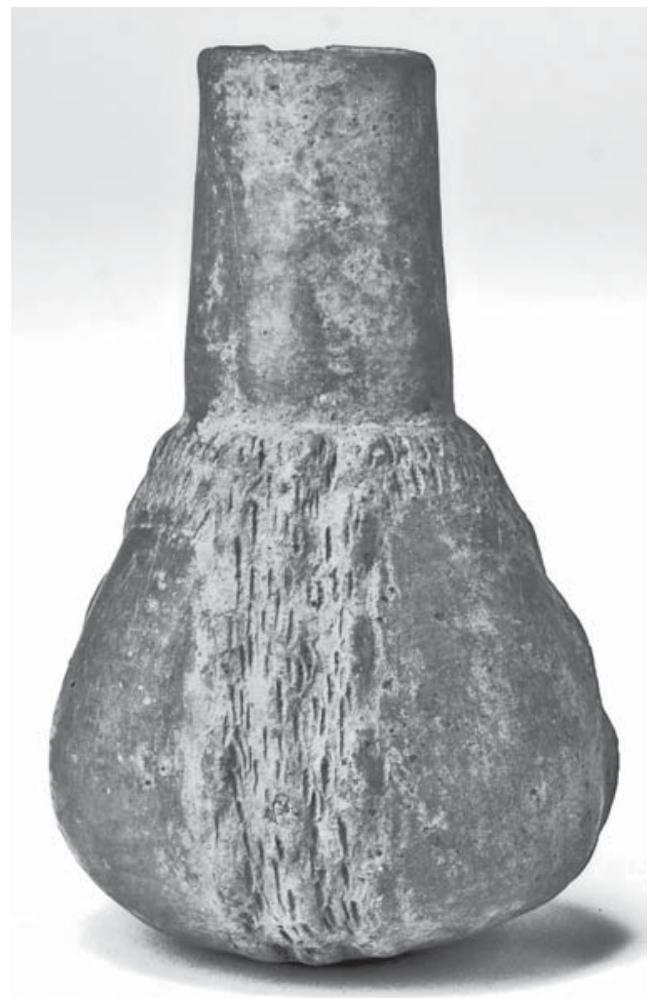

Figure 14. Maxey Noded Redware bottle from the T. M. Sanders site (41LR2).

SITE NAME OR SITE NUMBER: T. M. Sanders (41LR2)

VESSEL NO.: 428, GP 41063, TARL 2017.0131

VESSEL FORM: Bowl with opposed lip tabs (Figure 15a-b)

NON-PLASTICS AND PASTE: grog

RIM AND LIP FORM: Direct rim and rounded lip

CORE COLOR: $\mathrm{F}$ (fired in a reducing environment and cooled in the open air)

INTERIOR SURFACE COLOR: brown; fire clouds on the rim and body

EXTERIOR SURFACE COLOR: brown; fire clouds on the rim and body

WALL THICKNESS (IN MM): rim, 5.5

INTERIOR SURFACE TREATMENT: smoothed

EXTERIOR SURFACE TREATMENT: burnished 
HEIGHT (IN CM): 5.1

ORIFICE DIAMETER (IN CM): 10.6

DIAMETER AT BOTTOM OF RIM OR NECK (IN CM): N/A

BASE DIAMETER (IN CM) AND SHAPE OF BASE: $6.4 \mathrm{~cm}$, circular and concave

\section{ESTIMATED VOLUME (IN LITERS): 0.2}

DECORATION (INCLUDING MOTIF AND ELEMENTS WHEN APPARENT): The vessel rim area has two horizontal incised lines (Figure 15a). The top incised line is actually composed of $3+$ closely-spaced horizontal incised lines. The opposed lip tabs (Figure 15b) are $2.8 \mathrm{~cm}$ in width and $1.1 \mathrm{~cm}$ in height (Figure 15b).

PIGMENT USE AND LOCATION ON VESSEL: none

TYPE AND VARIETY (IF KNOWN): East Incised (see Suhm and Jelks 1962:Plate 21).
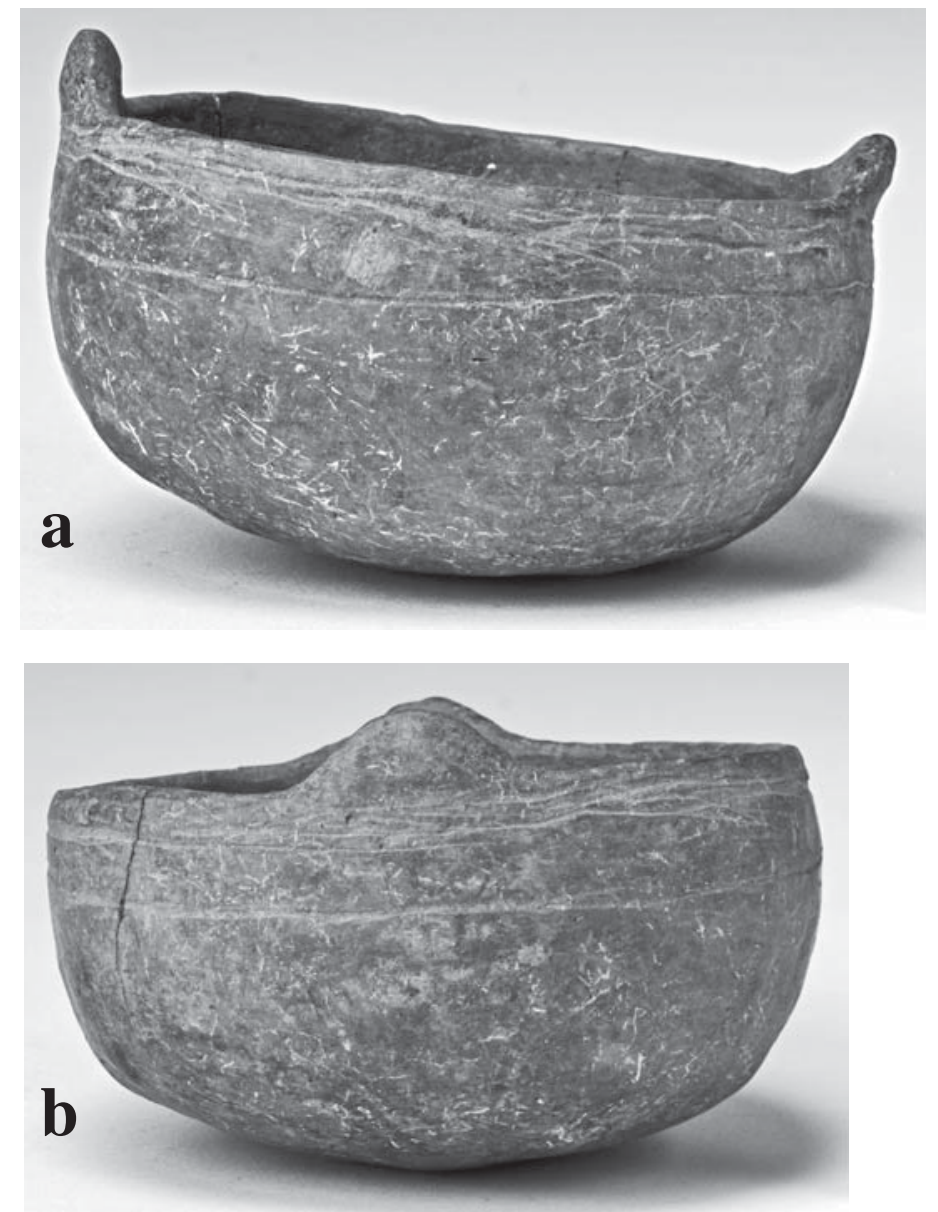

Figure 15. East Incised bowl from the T. M. Sanders site (41LR2): a, side view; b, lip tabs.

\section{Hooper Glover Farm Site (41MX4)}

The Hooper Glover Farm site (41MX4), in the northern part of the Big Cypress Creek basin in Morris County (see Thurmond 1990:Figure 1), was found by B. F. and L. P. Starrett sometime before 1930, when a broken Caddo ceramic vessel was found at the site after it had been plowed from a grave. The Starrett's explored the site and dug up an unknown number of burial features that contained 85 ceramic vessels and 57 stone artifacts, including 25 Talco arrow points and six celts. The range and character of the funerary objects from this ancestral Caddo cemetery suggest it was in use between ca. A.D. 1550-1680, during the latter part of the Titus phase.

The 85 vessels in the collection include ollas ( $n=4$, including the one vessel exchanged with the Gila Pueblo Museum), bowls $(n=8)$, bottles $(n=18)$, jars $(n=22)$, carinated bowls $(n=23)$, compound bowls $(n=5)$, and a double-chambered jar. The ceramic types present in the utility wares include Cass Appliqued, Harleton Appliqued, Maydelle Incised, and Mockingbird Punctated, with Bailey Engraved, Ripley Engraved (var. Galt, var. McKinney, and var. Pilgrims), Taylor Engraved, Turner Engraved, and Wilder Engraved as the fine ware types present in the cemetery vessel assemblage. 
SITE NAME OR SITE NUMBER: Hooper Glover Farm Site (41MX4)

VESSEL NO.: 4, GP 41061, TARL 2017.0131

VESSEL FORM: Olla

NON-PLASTICS AND PASTE: grog

RIM AND LIP FORM: Everted rim and rounded lip

CORE COLOR: $\mathrm{G}$ (fired in a reducing environment and cooled in the open air)

INTERIOR SURFACE COLOR: dark grayish-brown

EXTERIOR SURFACE COLOR: grayish-brown; fire clouds on the rim and body

WALL THICKNESS (IN MM): rim, 6.6

INTERIOR SURFACE TREATMENT: none

EXTERIOR SURFACE TREATMENT: smoothed

HEIGHT (IN CM): 20.9

ORIFICE DIAMETER (IN CM): 7.6

DIAMETER AT BOTTOM OF RIM OR NECK (IN CM): 7.4

BASE DIAMETER (IN CM) AND

SHAPE OF BASE: $7.0 \mathrm{~cm}$, circular and flat

ESTIMATED VOLUME (IN LITERS): 1.2

DECORATION (INCLUDING MOTIF AND ELEMENTS WHEN APPARENT): The vessel body has four sets of upward concentric engraved arches, and four sets of downward concentric engraved arches. Underneath the vessel neck, at the top of the vessel body, is a curvilinear engraved zone filled with small excised punctations.

PIGMENT USE AND LOCATION ON VESSEL: none

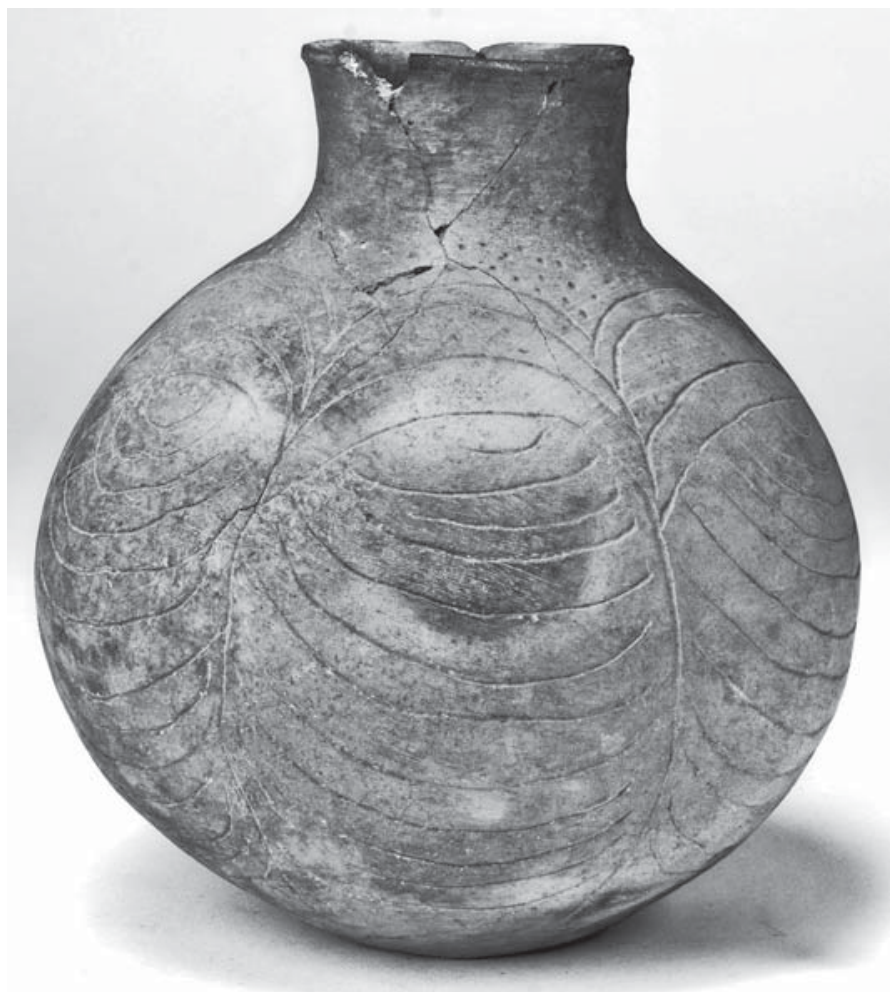

Figure 16. Bailey Engraved olla from the Hooper Glover farm (41MX4).

TYPE AND VARIETY (IF KNOWN): Bailey Engraved (Suhm and Jelks 1962:Plate 3) 


\section{Russell Brothers Site (41TT7)}

The Russell Brothers site was a Late Caddo period, Titus phase cemetery excavated by a UT crew in 1930 (Gardner 1930; Thurmond 1990:183). The cemetery was located in the floodplain of Swauano Creek in the Big Cypress Creek basin, and may have contained approximately 27 burial features. In addition to funerary offerings that included ceramic elbow pipes, Maud and Bassett arrow points, a stone earspool, celts, and hematite pigment stones, the burial features included 236 ceramic vessels. The cemetery was likely in use in the early part of the $16^{\text {th }}$ century A.D.

The principal fine wares in the ceramic vessel assemblage from the Russell Brothers site are Ripley Engraved (several varieties) and Wilder Engraved carinated bowls, compound bowls, and bottles, and there are several zoomorphic effigy bowls in the collection. Utility wares are represented primarily by Bullard Brushed, Maydelle Incised, and La Rue Neck Banded jars. About 9 percent of the vessels are plain carinated bowls, compound bowls, bottles, and jars (Thurmond 1990:183)

SITE NAME OR SITE NUMBER: Russell Brothers (41TT7)

VESSEL NO.: 216, GP 41060, TARL 2017.0131

VESSEL FORM: Carinated bowl

NON-PLASTICS AND PASTE: grog and bone

RIM AND LIP FORM: Direct rim and a flat lip

CORE COLOR: $\mathrm{G}$ (fired in a reducing environment and cooled in the open air)

INTERIOR SURFACE COLOR: dark grayish-brown

EXTERIOR SURFACE COLOR: light grayish-brown

WALL THICKNESS (IN MM): rim, 6.2

INTERIOR SURFACE TREATMENT: smoothed

EXTERIOR SURFACE TREATMENT: burnished

HEIGHT (IN CM): 6.0

ORIFICE DIAMETER (IN CM): 14.0

DIAMETER AT BOTTOM OF RIM OR NECK (IN CM): 12.6

BASE DIAMETER (IN CM) AND SHAPE OF BASE: $6.5 \mathrm{~cm}$, circular and flat ESTIMATED VOLUME (IN LITERS): 0.5 
DECORATION (INCLUDING MOTIF AND ELEMENTS WHEN APPARENT): The rim panel has a horizontal and vertical engraved scroll motif repeated four times around the vessel. The upper and lower scroll fill zones have columns, brackets, and triangle elements filled with cross-hatched lines, and these elements form negative ovals in the scroll fill zones (Figure 17).

\section{PIGMENT USE AND LOCATION}

ON VESSEL: white pigment in the engraved lines

TYPE AND VARIETY (IF

KNOWN): Ripley Engraved, var. Carpenter (see Fields et al. 2014; Perttula et al. 2012)

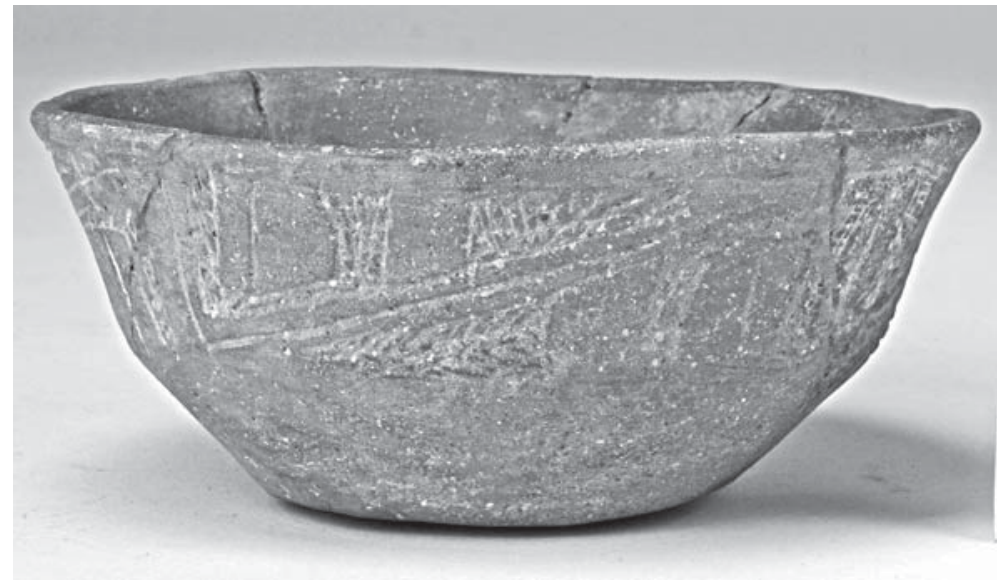

Figure 17. Ripley Engraved, var. Carpenter carinated bowl from the Russell Brothers site (41TT7).

\section{J.M. Riley Site (41UR2)}

The J. M. Riley Farm site had an ancestral Caddo cemetery of Late Caddo Titus phase affiliation that was excavated in 1931 by a UT crew (Jackson 1931). Eighteen graves were in the cemetery, and they contained an abundance of ceramic vessels $(n=179)$, as well as Talco arrow points, pipes, celts, a few other lithic artifacts $(n=6)$, and four burials with offerings of glauconitic clay masses (Thurmond 1990:Table 48). The most common ceramic types in the graves were Ripley Engraved (especially var. McKinney), Taylor Engraved, Wilder Engraved, and Harleton Appliqued, as well as lesser numbers of Simms Engraved, Avery Engraved, Belcher Engraved. Bowie Engraved, Bailey Engraved, Hodges Engraved, Johns Engraved, an effigy bowl, Cass Appliqued, Nash and La Rue Neck Banded, Bullard Brushed, Karnack Brushed-Incised, and Maydelle Incised. The common occurrence of Ripley Engraved, var. McKinney vessels and Talco arrow points in the graves suggest that this cemetery was in use in the latter part of the Titus phase, from ca. A.D. 1550-1680.

SITE NAME OR SITE NUMBER: J. M. Riley (41UR2)

VESSEL NO.: 6, GP 41053, TARL 2017.0131

VESSEL FORM: Bowl

NON-PLASTICS AND PASTE: grog

RIM AND LIP FORM: Direct rim and rounded, exterior folded, lip

CORE COLOR: F (fired in a reducing environment and cooled in the open air)

INTERIOR SURFACE COLOR: red

EXTERIOR SURFACE COLOR: red 
WALL THICKNESS (IN MM): rim, 6.2

INTERIOR SURFACE TREATMENT: smoothed

EXTERIOR SURFACE TREATMENT: burnished

HEIGHT (IN CM): 5.1

ORIFICE DIAMETER (IN CM): 10.8

DIAMETER AT BOTTOM OF RIM OR NECK (IN CM): N.A

BASE DIAMETER (IN CM) AND SHAPE OF BASE: $5.1 \mathrm{~cm}$, circular and flat

ESTIMATED VOLUME

(IN LITERS): 0.2

DECORATION

(INCLUDING MOTIF

AND ELEMENTS

WHEN APPARENT): The

vessel has an ochre-rich

red slip on interior and

exterior vessel surfaces

(Figure 18).

PIGMENT USE AND

LOCATION ON

VESSEL: none

TYPE AND VARIETY

(IF KNOWN):

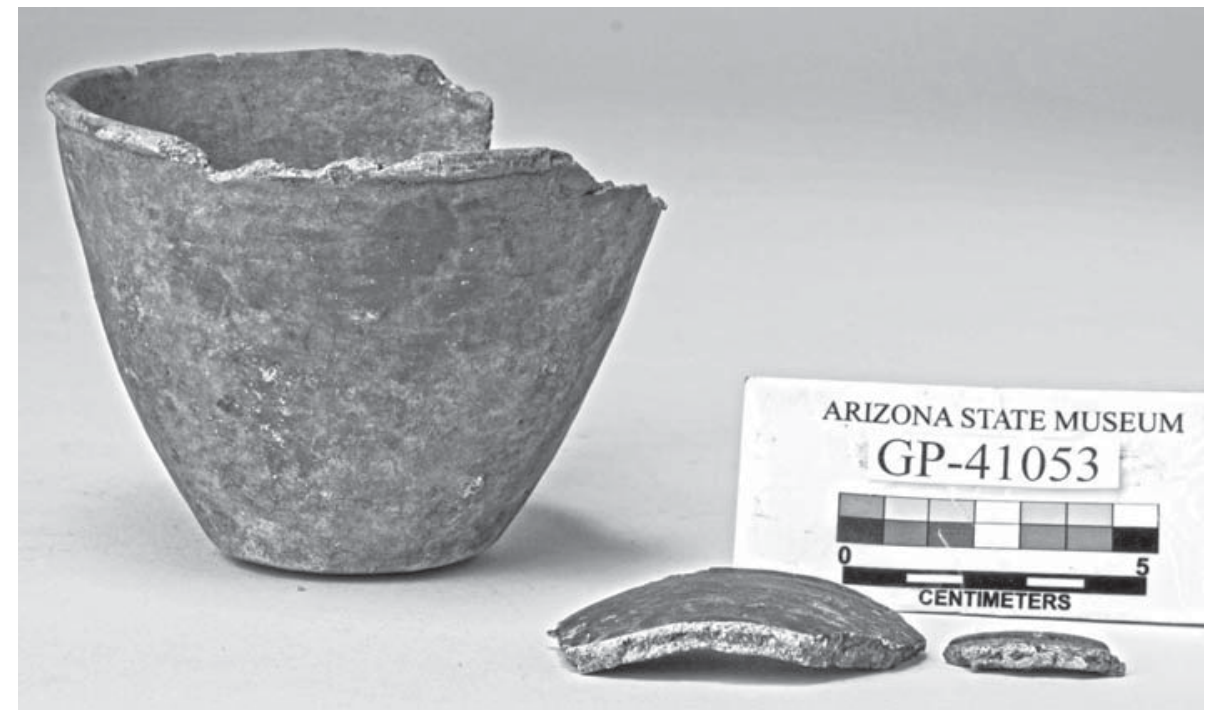

Unidentified fine ware

SITE NAME OR SITE NUMBER: J. M. Riley (41UR2)

VESSEL NO.: 81, GP 41055, TARL 2017.0131

VESSEL FORM: Carinated bowl

NON-PLASTICS AND PASTE: grog

RIM AND LIP FORM: Direct rim and rounded, exterior folded, lip

CORE COLOR: F (fired in a reducing environment and cooled in the open air)

INTERIOR SURFACE COLOR: reddish-brown

EXTERIOR SURFACE COLOR: reddish-brown; fire clouds on the rim, body, and base

WALL THICKNESS (IN MM): rim, 6.0 
INTERIOR SURFACE TREATMENT: burnished

EXTERIOR SURFACE TREATMENT: burnished

HEIGHT (IN CM): 7.2

ORIFICE DIAMETER (IN CM): 17.0

DIAMETER AT BOTTOM OF RIM OR NECK (IN CM): 16.4

BASE DIAMETER (IN CM) AND SHAPE OF BASE: $8.0 \mathrm{~cm}$, circular and flat

ESTIMATED VOLUME (IN LITERS): 0.7

DECORATION (INCLUDING MOTIF AND ELEMENTS WHEN APPARENT): The rim panel has two sets of central engraved diamond elements and two sets of engraved circles and brackets (Figure 19a-b). The engraved diamonds have a central excised dot, and they are connected to horizontal scroll lines that end in a vertical excised bracket (Figure 19a). Above and below the scroll lines are sets of large excised pendant triangles on upper and lower horizontal panel lines. Separating the horizontal scroll lines from the engraved circle central element are curvilinear excised lines. The circle elements have intersecting horizontal and vertical excised brackets, with an excised four-sided element at the intersection. These brackets form negative oval-shaped zones (Figure 19b). There is also a single horizontal engraved line at the carination on the interior vessel surface.

PIGMENT USE AND LOCATION ON VESSEL: none

TYPE AND VARIETY (IF KNOWN): Ripley Engraved, var. McKinney (Fields et al. 2014; Perttula et al. 2012) 
SITE NAME OR SITE NUMBER: J. M. Riley (41UR2)

VESSEL NO.: 215, GP 41054, TARL 2017.0131

VESSEL FORM: Jar

NON-PLASTICS AND PASTE: bone

RIM AND LIP FORM: Everted rim and rounded lip

CORE COLOR: G (fired in a reducing environment and cooled in the open air)

INTERIOR SURFACE COLOR: very dark grayish-brown; fire clouds on the rim and body

EXTERIOR SURFACE COLOR: light reddish-brown; fire clouds on the rim, body, and base

WALL THICKNESS (IN MM): rim, 6.5

INTERIOR SURFACE TREATMENT: smoothed

EXTERIOR SURFACE TREATMENT: none

HEIGHT (IN CM): 12.7

ORIFICE DIAMETER (IN CM): 13.3

DIAMETER AT BOTTOM OF RIM OR NECK (IN CM): 12.5

BASE DIAMETER (IN CM) AND

SHAPE OF BASE: $5.7 \mathrm{~cm}$, circular and flat

ESTIMATED VOLUME (IN LITERS): 1.0

DECORATION (INCLUDING MOTIF AND ELEMENTS WHEN APPARENT):

There are vertical brushing marks on the vessel rim that continue on the vessel body (Figure 20). The brushing on the body extends to within $2.5 \mathrm{~cm}$ of the vessel base.

PIGMENT USE AND LOCATION ON VESSEL: none

TYPE AND VARIETY (IF KNOWN): Bullard Brushed (see Suhm and Jelks 1962:Plate 11)

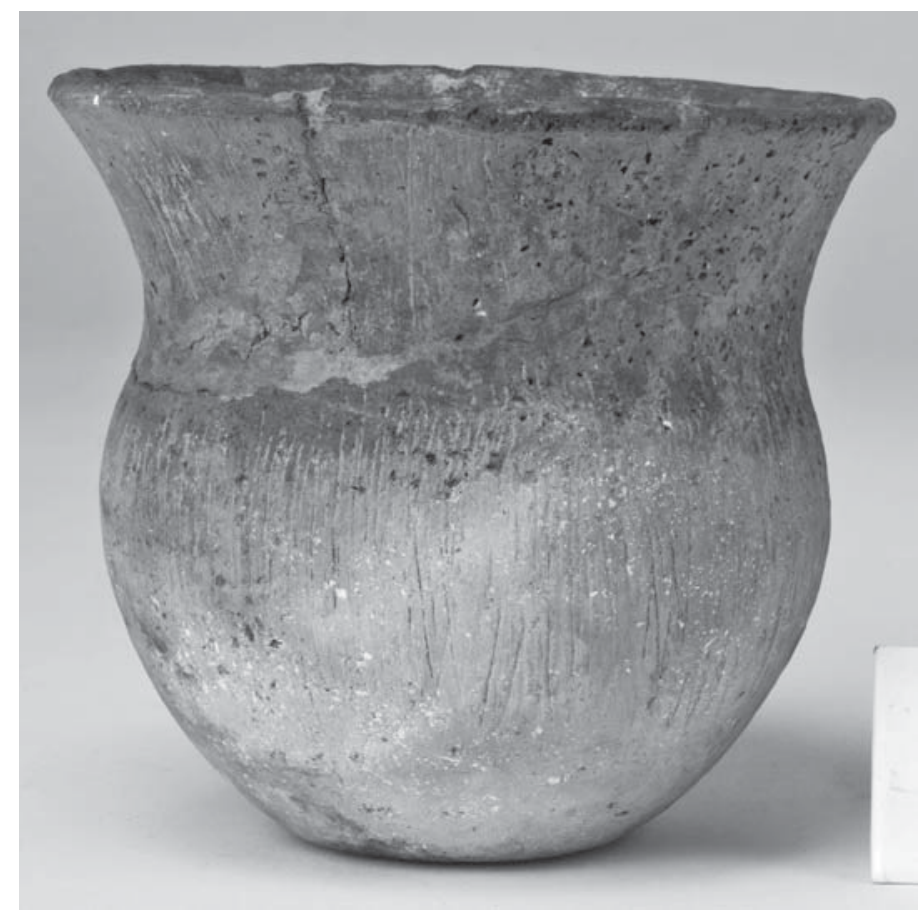

Figure 20. Bullard Brushed jar from the J. M. Riley site (41UR2). 
SITE NAME OR SITE NUMBER: J. M. Riley (41UR2)

VESSEL NO.: 276, GP 41065, TARL 2017.0131

VESSEL FORM: Jar (not reconstructed)

NON-PLASTICS AND PASTE: grog and hematite

RIM AND LIP FORM: Everted rim and rounded lip

CORE COLOR: $\mathrm{F}$ (fired in a reducing environment and cooled in the open air)

INTERIOR SURFACE COLOR: dark yellowish-brown; fire clouds on the rim and body

EXTERIOR SURFACE COLOR: yellowish-brown; fire clouds on the rim and body

WALL THICKNESS (IN MM): rim, $7.0 \mathrm{~mm}$; body, $6.4 \mathrm{~mm}$

INTERIOR SURFACE TREATMENT: smoothed

EXTERIOR SURFACE TREATMENT: none

HEIGHT (IN CM): 26.2+

ORIFICE DIAMETER (IN CM): 15.0

DIAMETER AT

BOTTOM OF RIM OR

NECK (IN CM): 14.2

BASE DIAMETER (IN CM) AND SHAPE OF

BASE: $9.8 \mathrm{~cm}$, circular and flat

ESTIMATED VOLUME (IN LITERS): $5.1+$

DECORATION (INCLUDING MOTIF AND ELEMENTS WHEN APPARENT): The rim has single horizontal incised lines at the top and bottom of the rim. Between these horizontal lines are four to five rows of tool punctations. The vessel body has vertical brushed-incised marks and lines that extend to within approximately $2.5 \mathrm{~cm}$ of the base (Figure 21).

PIGMENT USE AND LOCATION ON VESSEL: none

TYPE AND VARIETY (IF KNOWN): Karnack Brushed-Incised 


\section{Unknown Site}

An extra ceramic vessel was included with the other 20 vessels returned by the Arizona State Museum to TARL. Its site provenience is unknown, but the fact that the vessel is shell-tempered and has a distinctive shape, suggests it is from an ancestral Caddo site on the Red River. Shell-tempered vessels were commonly manufactured in the Late Caddo period (ca. A.D. 1400-1680) by Caddo potters living in several parts of the Red River in East Texas (see Perttula, Trubitt, and Girard 2012) occupied by McCurtain phase and Texarkana phase peoples, and inverted rim carinated bowls (see Suhm and Jelks 1962:Plate 71d, f) were also made in these areas after ca. A.D. 1550.

SITE NAME OR SITE NUMBER: Unknown

VESSEL NO.: GP 52501 (X-2), TARL 2017.0133

VESSEL FORM: carinated bowl

NON-PLASTICS AND PASTE: shell

RIM AND LIP FORM: Inverted rim and rounded lip

CORE COLOR: $\mathrm{G}$ (fired in a reducing environment and cooled in the open air)

INTERIOR SURFACE COLOR: dark grayish-brown

EXTERIOR SURFACE COLOR: reddish brown; fire clouds on the rim and body

WALL THICKNESS (IN MM): rim, $5.4 \mathrm{~mm}$; body, $6.8 \mathrm{~mm}$

INTERIOR SURFACE TREATMENT:

smoothed on the rim

EXTERIOR SURFACE TREATMENT:

burnished

HEIGHT (IN CM): 9.5

ORIFICE DIAMETER (IN CM): 15.9

DIAMETER AT BOTTOM OF RIM OR NECK (IN CM): 18.3

BASE DIAMETER (IN CM) AND SHAPE OF BASE: $7.3 \mathrm{~cm}$, circular and flat

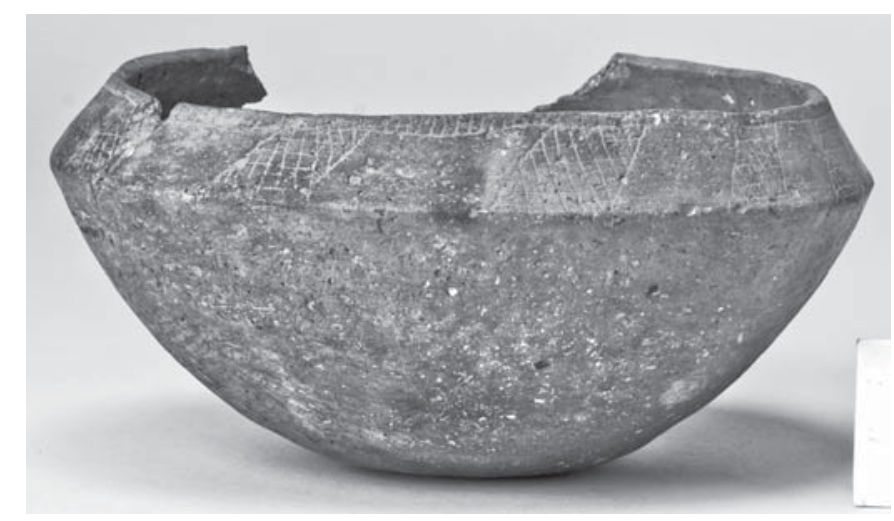

Figure 22. cf. Simms Engraved carinated bowl from an unknown East Texas site.

ESTIMATED VOLUME (IN LITERS): 0.9

DECORATION (INCLUDING MOTIF AND ELEMENTS WHEN APPARENT): The rim panel has a narrow horizontal zone under the vessel lip that is filled with short vertical and diagonal hatched lines. There are at least nine diagonal engraved zones on the rim panel (the exact number is not known since a $9.0 \mathrm{~cm}$ section of the rim is missing) that are filled with cross-hatched engraved lines (Figure 22).

PIGMENT USE AND LOCATION ON VESSEL: none

TYPE AND VARIETY (IF KNOWN): cf. Simms Engraved 


\section{Summary and Conclusions}

In the Summer of 201721 ancestral Caddo ceramic vessels that had been held in exchange between The University of Texas (UT) and the Arizona State Museum - and the Gila Pueblo Museum before that since 1933 - were returned to UT. These vessels had not been fully studied or documented by UT archaeologists before they were exchanged, so we took the opportunity to complete stylistic and technological analyses of these returned ceramic vessels from eight different East Texas Caddo sites. These sites are: Richard Patton (41AN26), Goode Hunt (41CS23), Culpepper Farm (41HP1), H. R. Taylor (41HS3), T. M. Sanders (41LR2), Hooper Glover (41MX4), Russell Brothers (41TT7), and J. M. Riley (41UR2); one vessel is from an unknown provenience, but likely from an ancestral Caddo site on the Red River.

The exchanged vessels from the T. M. Sanders site are from burial features in a Middle Caddo period (ca. A.D. 1200-1400) Sanders phase mound on the Red River. They include a Maxey Noded Redware bottle and an East Incised bowl. The fine ware and utility ware vessels from the Culpepper Farm, H. R. Taylor, Hooper Glover, Russell Brothers, and J. M. Riley sites are from Late Caddo period Titus phase sites (dating broadly from ca. A.D. 1430-1680) in the Big Cypress and Sulphur River basins in East Texas. These vessels include Ripley Engraved and Taylor Engraved carinated bowls, a Wilder Engraved bottle, a Bailey Engraved olla, a red-slipped bowl, Ripley Engraved compound bowls, and Bullard Brushed, Harleton Appliqued, and Karnack Brushed-Incised jars. Finally, the ceramic vessels from the Richard Patton and Goode Hunt sites are from late $17^{\text {th }}$ to early $18^{\text {th }}$ century Historic Caddo burial features in the upper Neches and Big Cypress drainage basins, respectively. These burial features were in cemeteries created and used by Hasinai and Nasoni Caddo peoples. The historic Caddo ceramics from the Richard Patton site are two different varieties of Patton Engraved, while both vessels from the Goode Hunt site are Simms Engraved carinated bowls.

\section{Acknowledgements}

We thank Lauren Bussiere and Marybeth Tomka at the Texas Archeological Research Laboratory at The University of Texas for facilitating access to the study of these vessels, and for providing photographs of the vessels taken by the Arizona State Museum. Lauren also provided comments on an earlier version of this article. Lance Trask prepared several figures in this article.

\section{References Cited}

Baumann, T. E., T. L. Gerke, and E. A. Reber

2013 Sun Circles and Science: Negative Painted Pottery from Angel Mounds (12Vg1). Midcontinental Journal of Archaeology 38(2):219-244.

Cole, N. M.

1975 Early Historic Caddoan Mortuary Practices in the Upper Neches Drainage, East Texas. Master's thesis, Department of Anthropology, The University of Texas at Austin.

Fields, R. C., V. L. Hatfield, D. Burden, E. F. Gadus, M. C. Wilder, and K. W. Kibler

2014 Testing and Data Recovery Excavations at 11 Native American Archeological Sites along the U.S. Highway 271 Mount Pleasant Relief Route, Titus County, Texas. 2 Vols. Reports of Investigations No. 168. Prewitt and Associates, Inc., Austin.

Gardner, B. B.

1930 Excavation of a Burial Site on W. S. Russell Farm, in Titus County, Texas. MS on file, Texas Archeological Research Laboratory, The University of Texas at Austin. 
Jackson, A. T.

1931 Notes on Fieldwork, J. M. Riley Farm, Upshur County, Texas. MS on file, Texas Archeological Research Laboratory, The University of Texas at Austin.

1932 Exploration of a burial site on Goode Hunt Farm in Cass County, Texas. MS on file, Texas Archeological Research Laboratory, The University of Texas at Austin.

Jackson, A. T., M. S. Goldstein, and A. D. Krieger

2000 The 1931 Excavations at the Sanders Site, Lamar County, Texas: Notes on the Fieldwork, Human Osteology, and Ceramics. Archival Series 2. Texas Archeological Research Laboratory, The University of Texas at Austin.

Marceaux, P. S.

2011 The Archaeology and Ethnohistory of the Hasinai Caddo: Material Culture and the Course of European Contact. Ph.D. dissertation, Department of Anthropology, The University of Texas at Austin.

Monaghan, G. W., T. Schilling, A. M. Krus, and C. S. Peebles

2013 Mound Construction Chronology at Angel Mounds: Episodic Mound Construction and Ceremonial Events. Midcontinental Journal of Archaeology 38(2):155-170.

Pearce, J. E. and A. T. Jackson

1931 Notes on Field Work, H. R. Taylor Farm, Harrison County, Texas, June 28, 1931 to July 22, 1931. MS on file, Texas Archeological Research Laboratory, The University of Texas at Austin.

Perttula, T. K.

2011 The Ceramic Artifacts from the Lang Pasture Site (41AN38) and the Place of the Site within an Upper Neches River Basin Caddo Ceramic Tradition. In Archeological Investigations at the Lang Pasture Site (41AN38) in the Upper Neches River Basin of East Texas, assembled and edited by T. K. Perttula, D. B. Kelley, and R. A. Ricklis, pp. 145-320. Archeological Studies Program Report No. 129, Texas Department of Transportation, Environmental Affairs Division, Austin.

2013 Caddo Ceramics in East Texas. Bulletin of the Texas Archeological Society 84:181-212.

2015 Caddo Ceramic Vessels from the Goode Hunt (41CS23) and Clements (41CS25) Sites in the East Texas Pineywoods. Special Publication No. 42. Friends of Northeast Texas Archaeology, Austin and Pittsburg.

2016 Documentation of the Caddo Ceramic Vessels from the Culpepper Site (41HP1) in Hopkins County in the Upper Sulphur River Basin in East Texas. Journal of Northeast Texas Archaeology 65:53-98.

2017 Ceramic Vessels and Other Funerary Objects in the H. R. Taylor (41HS3) Cemetery, Harrison County, Texas. Special Publication No. 46. Friends of Northeast Texas Archaeology, Austin and Pittsburg.

Perttula, T. K., P. S. Marceaux, and B. Nelson

2012 Study of the Margaret Hinton Collection of Pottery Vessels from Northeast Texas Caddo Cemeteries. Archeological \& Environmental Consultants, LLC, Austin and Pittsburg.

Perttula, T. K., P. S. Marceaux, B. Nelson, and M. Walters

2015 Caddo Ceramic Vessels from Sites in the Upper Neches River Basin of East Texas, Anderson and Cherokee Counties, Texas. Special Publication No. 37. Friends of Northeast Texas Archaeology, Austin and Pittsburg.

Perttula, T. K., M. B. Trubitt, and J. S. Girard

2012 The Use of Shell-Tempered Pottery in the Caddo Area of the Southeastern United States. Southeastern Archaeology 30(2):242-267.

Perttula, T. K., M. Walters, and B. Nelson

2016 Caddo Ceramic Vessels from the T. M. Sanders Site (41LR2) on the Red River in Lamar County, Texas. Special Publication No. 41. Friends of Northeast Texas Archaeology, Austin and Pittsburg. 
Perttula, T. K., M. Walters, K. Stingley, and T. Middlebrook

2017 Ceramic Vessels and Other Funerary Objects in the Titus Phase Cemetery at the Tuck Carpenter Site, Camp County, Texas. Special Publication No. 48. Friends of Northeast Texas Archaeology, Austin and Pittsburg.

Scurlock, J. D.

1962 The Culpepper Site, a Late Fulton Aspect Site in Northeast Texas. Bulletin of the Texas Archeological Society 32:285-316.

Suhm, D. A. and E. B. Jelks (editors)

1962 Handbook of Texas Archeology: Type Descriptions. Special Publication No. 1, Texas Archeological Society, and Bulletin No. 4, Texas Memorial Museum, Austin.

Thurmond, J. P.

1990 Archeology of the Cypress Creek Drainage Basin, Northeastern Texas and Northwestern Louisiana. Studies in Archeology 5. Texas Archeological Research Laboratory, The University of Texas at Austin. 